\title{
A $\beta$ Selectively Impairs mGluR7 Modulation of NMDA Signaling in Basal Forebrain Cholinergic Neurons: Implication in Alzheimer's Disease
}

\author{
Zhenglin Gu, ${ }^{1}$ Jia Cheng, ${ }^{1}$ Ping Zhong, ${ }^{1,2}$ Luye Qin, ${ }^{1}$ Wenhua Liu, ${ }^{1}$ and Zhen Yan ${ }^{1,2,3}$ \\ ${ }^{1}$ Department of Physiology and Biophysics, State University of New York at Buffalo, School of Medicine and Biomedical Sciences, Buffalo, New York 14214, \\ ${ }^{2}$ Veterans Administration Western New York Healthcare System, Buffalo, New York 14215, and ${ }^{3}$ Department of Neurobiology, Key Laboratory for \\ Neurodegenerative Disorders of the Ministry of Education, Capital Medical University, Beijing Institute for Brain Disorders, Beijing 100069, China
}

\begin{abstract}
Degeneration of basal forebrain (BF) cholinergic neurons is one of the early pathological events in Alzheimer's disease (AD) and is thought to be responsible for the cholinergic and cognitive deficits in AD. The functions of this group of neurons are highly influenced by glutamatergic inputs from neocortex. We found that activation of metabotropic glutamate receptor 7 (mGluR7) decreased NMDARmediated currents and NR1 surface expression in rodent BF neurons via a mechanism involving cofilin-regulated actin dynamics. In BF cholinergic neurons, $\beta$-amyloid $(\mathrm{A} \beta)$ selectively impaired mGluR7 regulation of NMDARs by increasing p21-activated kinase activity and decreasing cofilin-mediated actin depolymerization through a p $75^{\mathrm{NTR}}$-dependent mechanism. Cell viability assays showed that activation of mGluR7 protected BF neurons from NMDA-induced excitotoxicity, which was selectively impaired by A $\beta$ in BF cholinergic neurons. It provides a potential basis for the $\mathrm{A} \beta$-induced disruption of calcium homeostasis that might contribute to the selective degeneration of BF cholinergic neurons in the early stage of $\mathrm{AD}$.
\end{abstract}

Key words: actin; basal forebrain; beta-amyloid; cholinergic; mGluR; NMDA receptor

\section{Introduction}

Alzheimer's disease $(\mathrm{AD})$, a devastating neurodegenerative disorder, is characterized by the accumulation and aggregation of excessive $\beta$-amyloid peptides (A $\beta$ ), which triggers a complex cascade that leads to synaptic alterations, neurotransmitter deficiencies, and cognitive failure (Hardy and Higgins, 1992; Haass and Selkoe, 2007; Danysz and Parsons, 2012; Sivanesan et al., 2013). In addition, numerous studies have shown that a selective loss of basal forebrain (BF) cholinergic neurons is one of the most consistent and unique abnormalities associated with $\mathrm{AD}$ at the early stage (Perry et al., 1978; Whitehouse et al., 1982; Coyle et al., 1983; Vogels et al., 1990; Winkler et al., 1995). It forms the basis for the "cholinergic hypothesis" of dementia (Bartus et al., 1982; Muir, 1997). Enhancement of cholinergic function has been the major treatment for symptoms in $\mathrm{AD}$ patients. However, the cellular mechanisms underlying the selective loss of BF cholinergic neurons in $\mathrm{AD}$ are still largely unknown.

$\mathrm{BF}$ is composed of two major groups of neurons: cholinergic and GABAergic neurons (Gritti et al., 1993). BF neurons receive

\footnotetext{
Received March 25, 2014; revised Aug. 18, 2014; accepted Aug. 26, 2014.

Author contributions:Z.Y. designed research;Z.G., J.C.,P.Z., L.Q., and W.L. performed research;Z.G., J.C., P.Z., and W.L. analyzed data; Z.Y. wrote the paper.

This work was supported by Veterans Administration Merit Award 1101BX001633 to Z.Y. We thank Xiaoqing Chen and Dr. Qian Jiang for their technical support.

The authors declare no competing financial interests.

Correspondence should be addressed to Dr. Zhen Yan, Department of Physiology and Biophysics, State University of New York at Buffalo, 124 Sherman Hall, Buffalo, NY 14214. E-mail: zhenyan@buffalo.edu

DOI:10.1523/JNEUROSCI.1204-14.2014

Copyright $\odot 2014$ the authors $\quad 0270-6474 / 14 / 3413614-15 \$ 15.00 / 0$
}

intensive glutamatergic inputs primarily from cortical regions (Mesulam and Mufson, 1984; Zaborszky et al., 1997). These glutamatergic inputs activate both ligand-gated ion channels (ionotropic) and G-protein-coupled metabotropic receptors in BF neurons. It has been found that BF cholinergic neurons are vulnerable to the cytotoxic effects of glutamate analogues (Wenk and Willard, 1998). Overactivation of ionotropic glutamate receptors, especially NMDA receptors, is the key mechanism underlying excitotoxicity (Choi, 1992). Glutamate excitotoxicity has been suggested as one of the initiators of AD (Doble, 1999; Bordji et al., 2011). The newly approved therapeutic agent for moderate to severe $\mathrm{AD}$, memantine, is a low-affinity NMDAR antagonist that works to prevent excitotoxicity mediated by the excessive $\mathrm{Ca}^{2+}$ influx during sustained glutamate release (Cummings, 2004; Cosman et al., 2007). However, because of the ubiquitous distribution and important physiological function of NMDARs, direct NMDAR blockade could incur undesirable and serious side effects; thus, the clinical application is limited.

Metabotropic glutamate receptors (mGluRs), which are composed of eight subtypes (mGluR1-8), have been found to play a key role in neuronal communication and signal processing (Conn, 2003). The differential distribution of various mGluR subtypes on presynaptic and/or postsynaptic terminals puts them in a good position to provide subtle and localized modulation of ionotropic glutamate receptor functions (Baskys, 1992; Conn and Pin, 1997). Thus, mGluRs may serve as better targets for treatment of glutamate-related neurological disorders (Schoepp and Conn, 1993; Gubellini et al., 2004). 
Anatomic studies indicate that mGluR7 is highly expressed in $\mathrm{BF}$ regions, such as septal nucleus and nuclei of the diagonal band, whereas no significant expression of other members of Group III mGluRs is observed in these areas (Ohishi et al., 1995, Nakajima et al., 1993, Duvoisin et al., 1995). In this study, we found that activation of mGluR7 downregulated NMDAR currents in $\mathrm{BF}$ neurons, which was impaired by $\mathrm{A} \beta$ selectively in cholinergic neurons. Consistently, the mGluR7 protection of NMDA-induced excitotoxicity was selectively impaired by $\mathrm{A} \beta$ in $\mathrm{BF}$ cholinergic neurons. It provides a potential mechanism for the selective degeneration of this neuronal population in the early stage of $\mathrm{AD}$.

\section{Materials and Methods}

Acute-dissociation procedure and primary neuronal culture. Neurons from young (3-5 weeks postnatal) Sprague Dawley rats were acutely dissociated using procedures similar to those described previously ( $\mathrm{Gu}$ et al., 2005, 2012). All experiments were performed with the approval of State University of New York at Buffalo Animal Care Committee. Briefly, after incubation of brain slices in a $\mathrm{NaHCO}_{3}$-buffered saline, a small area containing nucleus basalis of Meynert (NBM) was dissected (Nakajima et al., 1985) and placed in an oxygenated chamber containing papain (1 $\mathrm{mg} / \mathrm{ml}$, Sigma) in HEPES-buffered Hank's balanced salt solution (HBSS, Sigma) at room temperature. After $40 \mathrm{~min}$ of papain digestion, tissue was rinsed three times in low $\mathrm{Ca}^{2+}$, HEPES-buffered saline and mechanically dissociated with a graded series of fire-polished Pasteur pipettes. The cell suspension was then plated into a $35 \mathrm{~mm}$ Lux Petri dish, which was then placed on the stage of a Nikon inverted microscope.

Neuronal cultures were prepared as previously described ( $\mathrm{Gu}$ et al., 2005,2009 ) with modification. Briefly, NBM area was dissected from E16 rat brain (Dunnett et al., 1986), and cells were dissociated using trypsin and trituration through a Pasteur pipette. The neurons were plated on coverslips coated with poly-L-lysine in DMEM with $10 \%$ FCS at a density of $1.0 \times 10^{5}$ cells $/ \mathrm{cm}^{2}$. When neurons attached to the coverslip within $24 \mathrm{~h}$, the medium was changed to Neurobasal with B27 supplement. Cytosine arabinoside (AraC, $1.25 \mu \mathrm{M}$ ) was added to the culture media on DIV4 to stop glia proliferation. Neurons were maintained for 10-14 d before being used for immunostaining.

$A \beta$ oligomer preparation and an $A D$ model. The procedure of $A \beta$ oligomer preparation was similar to what was described previously (Dahlgren et al., 2002; Gu et al., 2009). In brief, the $\mathrm{A} \beta_{1-42}$ peptide (Tocris Bioscience) was dissolved in hexafluoroisopropanol to $1 \mathrm{~mm}$. Hexafluoroisopropanol was then removed under vacuum. The remaining peptide was then resuspended in DMSO to $5 \mathrm{~mm}$ and diluted in $\mathrm{H}_{2} \mathrm{O}$ to 0.1 mM. The oligermeric $\mathrm{A} \beta$ was formed by incubating at $4^{\circ} \mathrm{C}$ for $24 \mathrm{~h}$.

$A P P$ transgenic mice carrying the Swedish mutation (K670N, M671L) were purchased from Taconic. Eight-week-old transgenic males (on B6SJLF1 hybrid background) were bred with mature B6SJLF1 females. Genetic background of these mice is the same with this breeding scheme. Genotyping were performed by PCR according to the manufacturer's protocol. Different ages of male transgenic and wild-type (WT) littermates were used in the experiments.

Whole-cell recordings. Recordings of NMDAR-mediated ionic currents used standard voltage-clamp techniques (Gu et al., 2005, 2012). The internal solution consisted of the following (in mM): $180 \mathrm{~N}$-methyl-Dglucamine (NMG), $40 \mathrm{HEPES}, 4 \mathrm{MgCl}_{2}, 0.1$ BAPTA, 12 phosphocreatine, $3 \mathrm{Na}_{2} \mathrm{ATP}, 0.5 \mathrm{Na}_{2} \mathrm{GTP}, 0.1$ leupeptin, pH 7.2-7.3, 265-270 mosm/L. The external solution consisted of the following (in mM): 127 $\mathrm{NaCl}, 20 \mathrm{CsCl}, 10$ HEPES, $1 \mathrm{CaCl}_{2}, 5 \mathrm{BaCl}_{2}, 12$ glucose, 0.001 TTX, 0.02 glycine, $\mathrm{pH}$ 7.3-7.4, 300-305 mOsm/L. Recordings were obtained with an Molecular Devices 200B patch-clamp amplifier that was controlled and monitored with an IBM PC running pCLAMP with a DigiData 1320 series interface (Axon Instruments). Electrode resistances were typically $2-4 \mathrm{M} \Omega$ in the bath. After seal rupture, series resistance $(4-10 \mathrm{M} \Omega$ ) was compensated $(70 \%-90 \%)$ and periodically monitored. The cell membrane potential was held at $-60 \mathrm{mV}$. NMDA $(100 \mu \mathrm{M})$ was applied for $2 \mathrm{~s}$ every $30 \mathrm{~s}$ to minimize desensitization-induced decrease of current amplitude. Peak values were measured for generating the plot as a function of time and drug application. Drugs were applied with a gravity-fed "sewer pipe" system. The array of application capillaries ( $\sim 150 \mu \mathrm{m}$ i.d.) was positioned a few hundred microns from the cell under study. Solution changes were effected by the SF-77B fast-step solution stimulus delivery device (Warner Instrument). The voltage-dependent $\mathrm{Ca}^{2+}$ current (VDCC) was evoked by a voltage ramp protocol.

The whole-cell voltage-clamp technique was used to measure NMDAR-EPSC in BF slices (Gu et al., 2005, 2009). The slice $(300 \mu \mathrm{m})$ was incubated with ACSF containing bicuculline (10 $\mu \mathrm{M})$ and CNQX (20 $\mu \mathrm{M})$. The internal solution contained the following (in $\mathrm{mM}$ ): $130 \mathrm{Cs}$ methanesulfonate, $10 \mathrm{CsCl}, 4 \mathrm{NaCl}, 1 \mathrm{MgCl}_{2}, 10 \mathrm{HEPES}, 5$ EGTA, 2.2 QX-314, 12 phosphocreatine, 5 MgATP, $0.5 \mathrm{Na}_{2} \mathrm{GTP}$, pH 7.2-7.3, 265270 mosM. Neurons were visualized with a $40 \times$ water-immersion lens and illuminated with near infrared light. All recordings were performed using a Multiclamp 700A amplifier. Tight seals (2-10 G $\Omega$ ) were generated by applying negative pressure. Additional suction was applied to disrupt the membrane and obtain the whole-cell configuration. EPSCs were evoked by stimulating the neighboring neurons with a bipolar tungsten electrode (FHC) located at a few hundred micrometers away from the neuron under recording. Before stimulation, neurons were held at $-70 \mathrm{mV}$ and then depolarized to $60 \mathrm{mV}$ for $3 \mathrm{~s}$ to fully relieve the voltage-dependent $\mathrm{Mg}^{2+}$ block of NMDARs.

Data analyses were performed with Clampfit (Axon Instruments) and Kaleidagraph (Albeck Software). ANOVA tests were performed to compare the differential degrees of current modulation between groups subjected to different treatments.

Immunocytochemical staining. Neurons grown on coverslips were fixed in 4\% PFA in PBS for $20 \mathrm{~min}$ at room temperature and then washed 3 times with PBS. Neurons were then permeabilized with $0.1 \%$ Triton $\mathrm{X}-100$ in PBS for 5 min, followed by $1 \mathrm{~h}$ incubation with 5\% BSA to block nonspecific staining. For the staining of surface NR1, neurons were fixed but not permeabilized. Neurons were incubated with primary antibodies at $4^{\circ} \mathrm{C}$ overnight. Antibodies used include the following: anti-ChAT (1:500, Millipore Bioscience Research Reagents), anti-MAP2 (1:500, Millipore Bioscience Research Reagents), anti-NR1 (extracellular domain, 1:100, Millipore Bioscience Research Reagents), anti-p-cofilin (1:100, Cell Signaling), anti-cofilin (1:100, Cell Signaling), anti-p-PAK (1:100, Cell Signaling), anti-PAK (1:100, Biosource), and anti-p75 ${ }^{\text {NTR }}$ (1:500, Millipore Bioscience Research Reagents).

After washing, neurons were incubated with Alexa-647 (blue), Alexa488 (green), or Alexa-594 (red)-conjugated secondary antibodies (Molecular Probes, 1:500) for $2 \mathrm{~h}$ at room temperature. For the staining of F-actin, neurons were incubated with Alexa-568-conjugated phalloidin (1 U/ml, Invitrogen) at room temparature for $15 \mathrm{~min}$. After washing in PBS for three times, coverslips were mounted on slides with VECTASHIELD mounting media (Vector Laboratories).

Fluorescent images were obtained using a $40 \times$ or $100 \times$ objective with a cooled CCD camera mounted on a Nikon microscope. All specimens were imaged under identical conditions and analyzed using identical parameters with the ImageJ software. The surface NR1 clusters or F-actin clusters were measured. To define dendritic clusters, a single threshold was chosen manually, so that clusters corresponded to puncta of at least twofold greater intensity than the diffuse fluorescence on the dendritic shaft. On each coverslip, the cluster density of 4-6 neurons (3-4 dendritic segments of $100 \mu \mathrm{m}$ length per neuron) was measured. The fluorescence intensity of p-cofilin or p-PAK staining was assessed by tracing a region around individual neurons (including the soma and proximal dendrites) and measuring the average intensity of pixels in the region (background was subtracted using the threshold method). Three or four independent experiments for each of the treatments were performed. Quantitative analyses were conducted blindly (without knowledge of experimental treatment).

Single-cell RT-PCR. Single-cell RT-PCR was performed as previously described ( $\mathrm{Gu}$ et al., 2007). In brief, a single neuron was aspirated into the recording electrode by negative pressure after recording. Electrodes contained $\sim 5 \mu \mathrm{l}$ of sterile recording solution. After aspiration, the tip of the electrode was broken, and contents were ejected into $0.5 \mathrm{ml}$ Eppendorf tube containing $3 \mu \mathrm{l}$ DEPC-treated water, $1 \mu \mathrm{l}$ oligo $(\mathrm{dT})(0.5 \mu \mathrm{g} / \mu \mathrm{l}), 0.5$ $\mu \mathrm{l}$ Rnasin $(40 \mathrm{U} / \mu \mathrm{l}), 0.5 \mu \mathrm{lDTT}(0.1 \mathrm{M})$. The mixture was heated to $70^{\circ} \mathrm{C}$ for $10 \mathrm{~min}$ and then incubated on ice for $1 \mathrm{~min}$. First-strand cDNA was 
A

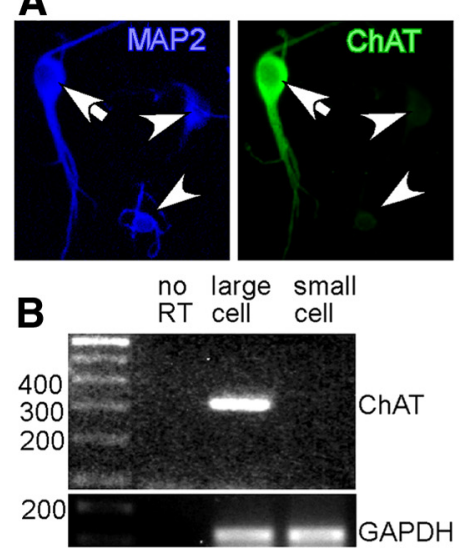

C

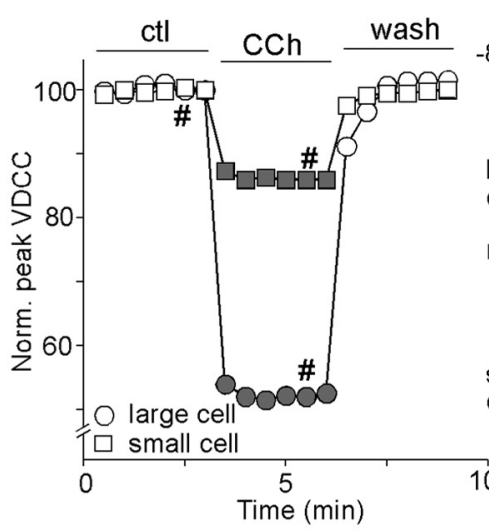

D

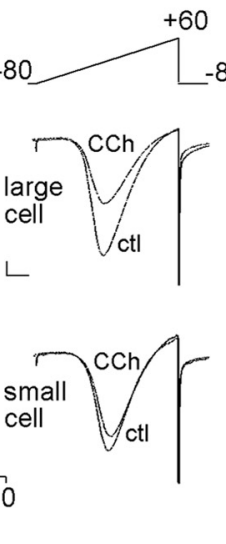

E

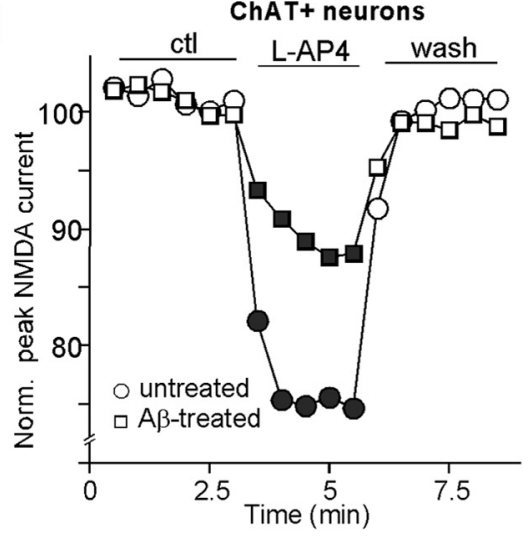

F

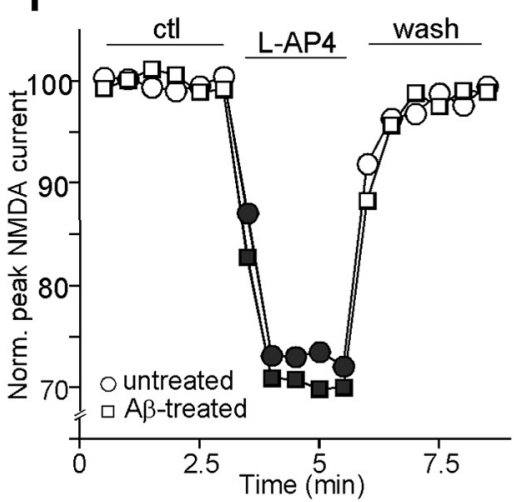

G
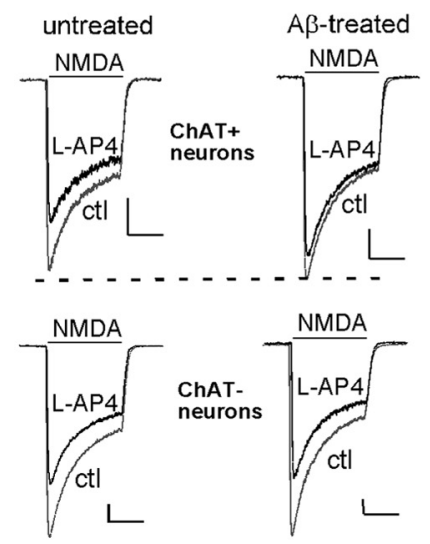

H

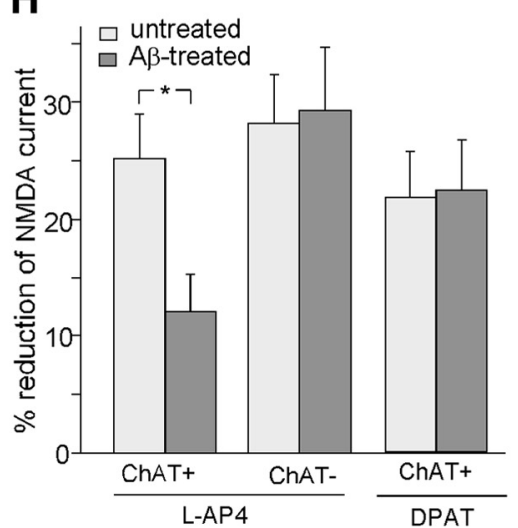

Figure 1. Activation of mGluR7 reduced NMDAR currents in BF neurons, which was selectively impaired by $A \beta$ in BF cholinergic neurons. $A$, Immunocytochemical images showing the costaining

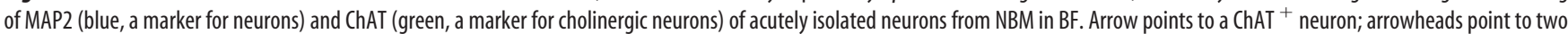
ChAT ${ }^{-}$neurons. $B$, Single-cell RT-PCR showing the expression of ChAT mRNA in acutely dissociated BF neurons. C, Plot of normalized peak VDCCs showing the effect of carbachol (20 $\left.\mu \mathrm{m}\right)$, a cholinergic receptor agonist, in dissociated BF large neurons (cholinergic) and small neurons (noncholinergic). Inset, Representative VDCC traces evoked by a voltage ramp (at time points denoted by \#). Calibration: $0.2 \mathrm{nA}, 25 \mathrm{~ms}$. D, Cumulative data (mean \pm SEM) showing the percentage reduction of VDCC by carbachol in BF large (cholinergic) and small (noncholinergic) neurons. ${ }^{*} p<0.01$ (ANOVA).E, $\boldsymbol{F}$, Plot of normalized peak NMDAR currents showing the L-AP4 $(200 \mu \mathrm{M})$ effect in BF cholinergic $(\boldsymbol{E})$ and noncholinergic $(\boldsymbol{F})$ neurons isolated from slices treated with or without oligomeric $A \beta(1 \mu \mathrm{m}, 2 \mathrm{~h})$. The fast washout of $\mathrm{L}-\mathrm{AP} 4$ in dissociated neurons led to the speedy recovery of NMDAR currents. $\boldsymbol{G}$, Representative current traces taken from the records used to construct $\boldsymbol{E}$ and $\boldsymbol{F}$. Calibration: $0.1 \mathrm{nA}, 1 \mathrm{~s}$. H, Cumulative data (mean \pm SEM) showing the percentage reduction of NMDAR currents by L-AP4 or 8-OH-DPAT (5-HT $1 \mathrm{~A}$ agonist, $20 \mu \mathrm{M})$ in BF cholinergic and noncholinergic neurons with or without $A \beta$ treatment. ${ }^{*} p<0.005$ (ANOVA).

synthesized from the total mRNA by adding Superscript III RT $(1 \mu l, 200$ $\mathrm{U} / \mu \mathrm{l})$ and $2 \mu \mathrm{l}$ buffer $(10 \times), 1 \mu \mathrm{l}$ DTT $(0.1 \mathrm{M}), 1 \mu \mathrm{ldNTP}(10 \mu \mathrm{M}), 4 \mu \mathrm{l}$ $\mathrm{MgCl}_{2}(25 \mathrm{~mm})$. The mixture was then incubated at $42^{\circ} \mathrm{C}$ for $50 \mathrm{~min}$ and terminated by heating the mixture to $70^{\circ} \mathrm{C}$ for $15 \mathrm{~min}$ and then icing. The RNA strand was removed by adding $1 \mu \mathrm{l}$ RNase $\mathrm{H}(2 \mathrm{U} / \mu \mathrm{l})$ and incubated for $20 \mathrm{~min}$ at $37^{\circ} \mathrm{C}$. The cDNA was then subjected to 45 cycles of
PCR amplification. The primers used for ChAT amplification were as follows: 5' -ATG GCC ATT GAC AAC CAT CTT CTG and 5' -CCT TGA ACT GCA GAG GTC TCT CAT (PCR product: $324 \mathrm{bp}$ ). The primers used for GAPDH amplification were as follows: $5^{\prime}$-GAC AAC TCC CTC AAG ATT GTC AG and 5'-ATG GCA TGG ACT GTG GTC ATG AG (PCR product: $122 \mathrm{bp}$ ). 
A

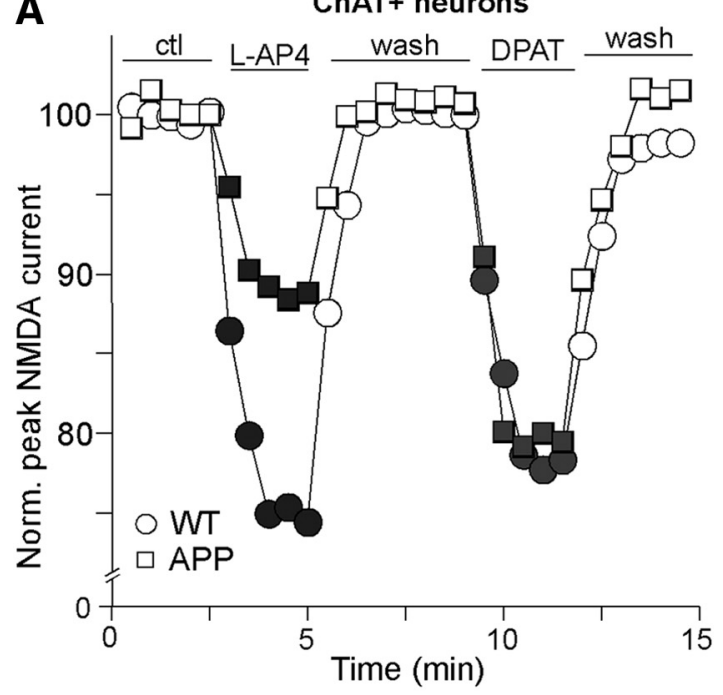

C

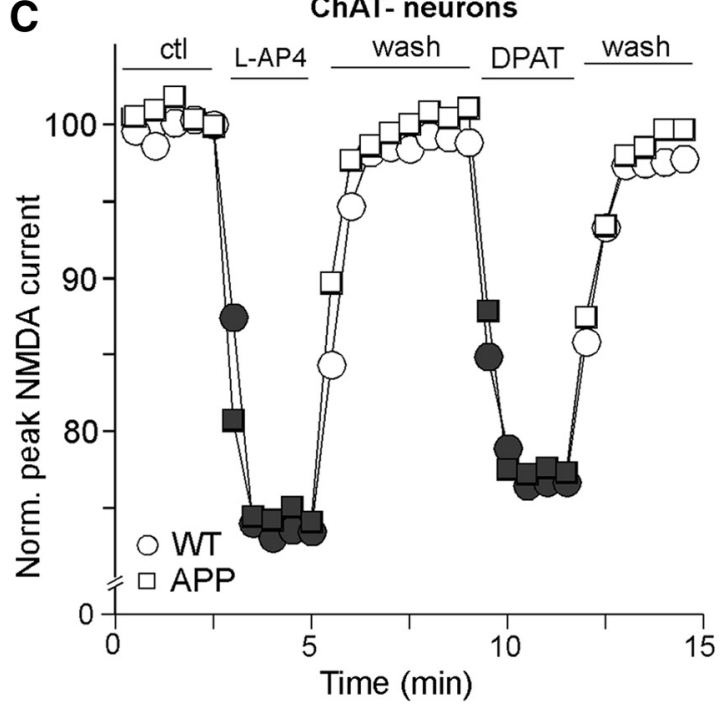

B ChAT+ neurons

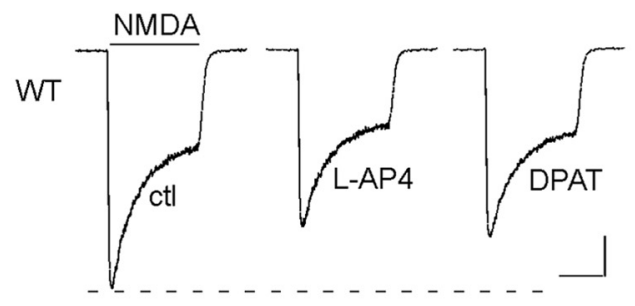

APP

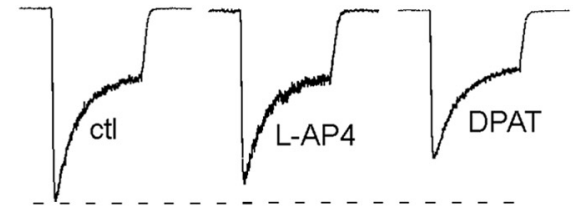

$\mathbf{D}$

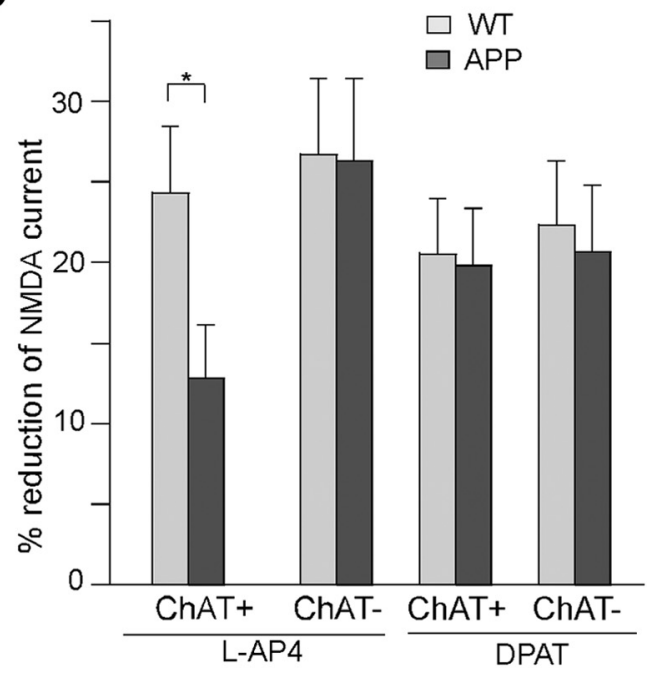

Figure 2. The mGluR7 regulation of NMDAR currents was selectively impaired in BF cholinergic neurons from APP transgenic mice. $A, C$, Plot of normalized peak NMDAR currents showing the effect of L-AP4 $(200 \mu \mathrm{m})$ and 8-OH-DPAT $(20 \mu \mathrm{M})$ in BF cholinergic $(\boldsymbol{A})$ or noncholinergic $(\boldsymbol{C})$ neurons from WT or APP transgenic mice. $\boldsymbol{B}$, Representative current traces taken from the records used to construct $A$. Calibration: $0.1 \mathrm{nA}, 1$ s. D. Cumulative data (mean \pm SEM) showing the percentage reduction of NMDAR currents by L-AP4 or 8-OH-DPAT in BF cholinergic and noncholinergic neurons from WT versus APP mice. ${ }^{*} p<0.005$ (ANOVA).

Neuronal viability assay. For the detection of apoptosis, BF cultures (DIV 14), $24 \mathrm{~h}$ after treatment, were stained with MAP2 and ChAT to label live cholinergic and noncholinergic neurons, and propidium iodide (PI) to label apoptotic neurons as we previously described (Deng et al., 2014). In brief, neurons were fixed and permeabilized, followed by the incubation in BSA to block nonspecific staining. Then neurons were incubated with anti-MAP2 (1:1000, Millipore Bioscience Research Reagents) and anti-ChAT (1:500, Millipore Bioscience Research Reagents) for $2 \mathrm{~h}$ at room temperature. After washing off the primary antibodies, neurons were incubated in Alexa-647 (blue) and Alexa-488 (green)-conjugated secondary antibodies (1:200, Invitrogen) for $2 \mathrm{~h}$ at room temperature. After three washes in PBS, neurons were exposed to PI ( $4 \mu \mathrm{g} / \mathrm{ml}$, Sigma) for $10 \mathrm{~min}$ at room temperature. Coverslips were washed and mounted. The number of live cholinergic $\left(\mathrm{MAP}^{+} / \mathrm{ChAT}^{+}\right)$and noncholinergic $\left(\mathrm{MAP}^{+} / \mathrm{ChAT}^{-}\right)$neurons in untreated versus treated conditions were compared. At least five coverslips from independent experiments were examined for each condition. The percentage of apoptotic neurons following different treatments, as indicated by PI-stained condensed nucleus, were also compared.
In vivo excitotoxic lesion and histochemistry. NMDA (60 mM, dissolved in PBS, $0.01 \mathrm{M}, \mathrm{pH} 7.4)$ was injected $(1 \mu \mathrm{l})$ slowly $(0.1 \mu \mathrm{l} / \mathrm{min})$ into the right NBM (anteroposterior, $0.6 \mathrm{~mm}$; lateral, $1.9 \mathrm{~mm}$; dorsoventral, 4.7 $\mathrm{mm}$ ) with a Hamilton syringe. The protective role of mGluR7 or TATPAK18 peptide in vivo was examined by administration of L-AP4 (i.p.) or TAT-PAK18 (i.v.) before the excitotoxic lesion. The impact of $A \beta$ on the mGluR7 function was examined by administration (i.p.) of A $\beta$ antibody ( $3 \mathrm{mg} / \mathrm{kg}$, Sigma) before the treatment of L-AP4. One day after NMDA injection, the mice were deeply anesthetized and fixed. The brains were cut into $30-\mu \mathrm{m}$-thick coronal sections using a freezing microtome. To assess neuronal loss, sections were stained for Nissl substance with cresyl violet. To assess neuronal survival, sections were transferred to a PBS solution, incubated in $0.5 \% \mathrm{H}_{2} \mathrm{O}_{2}$ (30 min), blocking solution $(1 \mathrm{~h})$, and then the ChAT antibody $(24 \mathrm{~h})$. The secondary antibody incubation, avidin biotin complex (ABC Elite kit) step, and $3^{\prime}$-diaminobenzidine incubation were each preceded and followed by rinses in PBS. Finally, the sections were mounted on gelatin-coated slides, dehydrated, and then coverslipped. The number of $\mathrm{ChAT}^{+}$neurons was counted in the NBM region $\left(\sim 0.5 \mathrm{~mm}^{2}\right)$ from WT versus APP transgenic mice. 


\section{Results}

Activation of mGluR7 reduces NMDAR currents in BF neurons, and $\mathrm{A} \beta$ selectively impairs mGluR7 effects in BF cholinergic neurons

$\mathrm{BF}$ is mainly composed of cholinergic and noncholinergic (mainly GABAergic) neurons. Cholinergic neurons usually have oval-shaped, larger $(>20 \mu \mathrm{m}$ in diameter) cell bodies (Nakajima et al., 1985; Griffith et al., 1994; Jassar et al., 1999). We first used the morphological features to select neurons acutely isolated from BF slices and then used immunocytochemical staining and single-cell mRNA profiling to confirm the identity of these cells. As shown in Figure 1A, BF neurons positive for ChAT usually exhibited larger cell bodies. In a sample of neurons we tested, $>90 \%$ of the large cells $(n=18)$ were positive for ChAT mRNA expression, whereas all the small cells $(n=14)$ were ChAT-negative (Fig. $1 B$ ), suggesting that the soma size of these dissociated neurons can be used as a reliable index of their identity. In addition, the VDCC was reduced by the muscarinic acetylcholine receptor agonist carbachol $(20 \mu \mathrm{M})$ to a much larger extent in BF cholinergic neurons, compared with noncholinergic neurons (Fig. $1 C$; cholinergic: $51.6 \pm 6.2 \%$, $n=10$; noncholinergic: $14.5 \pm 2.7 \%, n=$ 10; Fig. 1D), which can be used as another feature to distinguish these cells.

To test the potential impact of cortical glutamatergic inputs on the synaptic transmission of BF, we examined the effect of various metabotropic glutamate receptors (mGluRs) on the currents mediated by AMPAR, NMDAR, and $\mathrm{GABA}_{\mathrm{A}} \mathrm{R}$ channels in BF neurons. We found that L-AP4 $(200 \mu \mathrm{M})$, a selective Group III mGluR agonist, caused a significant reduction of NMDA (100 $\mu \mathrm{M})$-elicited ionic currents in BF cholinergic neurons (22.7 \pm $3.4 \%, n=15)$ and noncholinergic neurons $(23.3 \pm 3.7 \%, n=8)$. However, L-AP4 did not significantly alter AMPAR or $\mathrm{GABA}_{\mathrm{A}} \mathrm{R}$ currents in both types of BF neurons (AMPAR: cholinergic, $2.2 \pm$ $2.0 \%, n=6$; noncholinergic, $1.8 \pm 2.4 \%, n=6$; $\mathrm{GABA}_{\mathrm{A}} \mathrm{R}$ : cholinergic, $1.5 \pm 1.6 \%, n=6$; noncholinergic, $1.3 \pm 1.7 \%, n=6$ ). Similar to what we found in cortical neurons (Gu et al., 2012), the effect of L-AP4 on NMDAR currents was largely blocked by Group III mGluR antagonists CPPG $(50 \mu \mathrm{M})$ or M-SOP (400 $\mu \mathrm{M})$, and lower doses of L-AP4 $(20-50 \mu \mathrm{M})$ did not have significant effects on NMDAR currents. Since cell line studies (Conn and Pin, 1997; Schoepp et al., 1999) have shown that L-AP4 has $\mathrm{EC}_{50}$ of $160-500 \mu \mathrm{M}$ to mGluR7 and $0.4-1.2 \mu \mathrm{M}$ to other members in Group III (mGluR4, 6, 8), our data suggest that mGluR7 is the receptor mediating the effect of L-AP4 on NMDARs.

Given the involvement of BF cholinergic system in AD (Coyle et al., 1983), we examined the impact of $\mathrm{A} \beta$ on mGluR7 regulation of NMDARs in BF neurons. The basal NMDAR currents in $\mathrm{BF}$ neurons from untreated versus $\mathrm{A} \beta$ oligomer $(1 \mu \mathrm{M}, 2 \mathrm{~h})$ treated slices were not significantly different (untreated: $541 \pm 33$ $\mathrm{pA}, n=8$; $\mathrm{A} \beta$-treated: $528 \pm 36 \mathrm{pA}, n=8)$. However, as shown in Figure $1 E-G$, incubation with $A \beta$ oligomer significantly im-
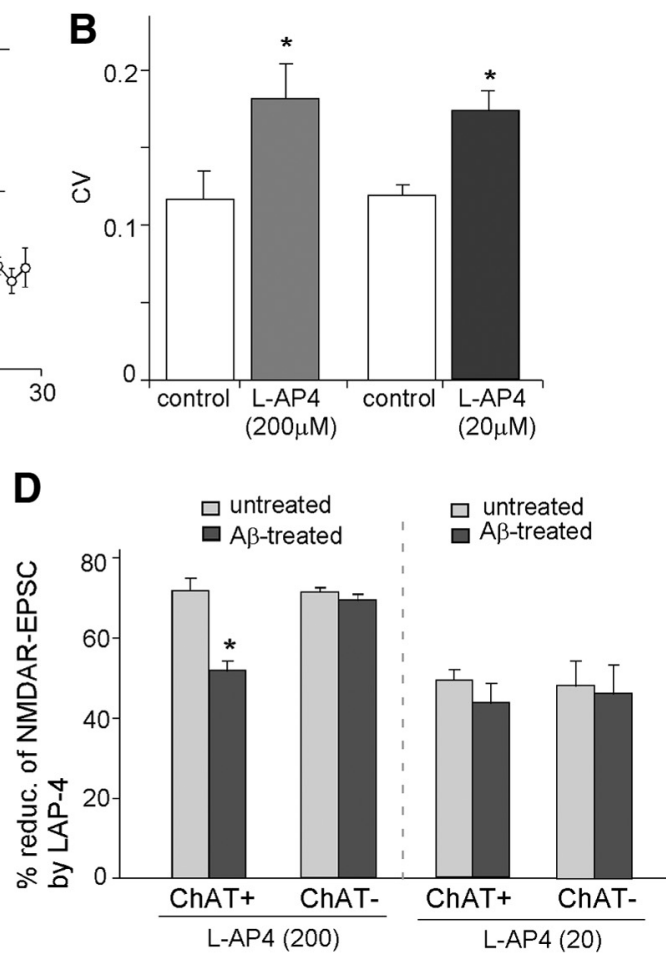

re 3. Activation of $m G l u R 7$ reduced NMDAR-mediated synaptictransmission in BF neurons, which was selectively impaired amplitudes in cells before and during L-AP4 application. $D$, Cumulative data showing the percentage reduction of NMDAR-EPSC by L-AP4 (20 or $200 \mu \mathrm{m})$ in BF cholinergic and noncholinergic neurons with A $\beta$ treatment. ${ }^{*} p<0.01$ (ANOVA).

paired the effect of L-AP4 on NMDAR currents in BF cholinergic neurons (A $\beta$-treated: $12.1 \pm 3.2 \%, n=9$; control: $25.2 \pm 3.8 \%$, $n=8, p<0.001$; Fig. $1 H)$, whereas no significant impairment was seen in noncholinergic neurons (A $\beta$-treated: $29.3 \pm 5.4 \%$, $n=8$; control: $28.2 \pm 4.2 \%, n=8$; Fig. $1 H$ ). Moreover, the effect of $5-\mathrm{HT}_{1 \mathrm{~A}}$ receptor agonist $8-\mathrm{OH}-\mathrm{DPAT}(20 \mu \mathrm{M})$ on NMDAR currents was not altered by $\mathrm{A} \beta$ treatment in BF cholinergic neurons (A $\beta$-treated: $22.4 \pm 4.3 \%, n=8$; control: $21.8 \pm 3.9 \%, n=$ 8; Fig. $1 H$ ), suggesting the selective impact of $\mathrm{A} \beta$ on mGluR7 signaling in these cells.

We further tested the effect of L-AP4 on NMDAR currents in the AD model overexpressing mutated APP (Hsiao et al., 1996; Chapman et al., 1999). The basal NMDAR currents in BF neurons from WT versus $A P P$ transgenic mice were not significantly different (WT: $514 \pm 31 \mathrm{pA}, n=8$; APP: $503 \pm 34 \mathrm{pA}, n=8$ ). Impaired L-AP4 regulation of NMDAR currents was found only in $\mathrm{BF}$ cholinergic neurons from $A P P$ transgenic mice (Fig. $2 A, B$; 3-month-old APP: $12.8 \pm 3.4 \%, n=12$; age-matched WT: $24.3 \pm 4.2 \%, n=9, p<0.001$; Fig. $2 D)$, but not in noncholinergic neurons (Fig. $2 C$; APP: $26.3 \pm 5.2 \%, n=8$; WT: $26.7 \pm$ $4.8 \%, n=8$; Fig. $2 D$ ). The $5-\mathrm{HT}_{1 \mathrm{~A}}$ regulation of NMDAR currents was intact in both types of BF neurons from APP transgenic mice (Fig. 2D). These results suggest that $\mathrm{A} \beta$ selectively impaired mGluR7 regulation of NMDAR-mediated ionic currents in BF cholinergic neurons.

Next, we examined whether activation of Group III mGluRs affected NMDAR-mediated synaptic responses in BF neurons. As shown in Figure $3 A$, application of L-AP4 $(200 \mu \mathrm{M})$ induced a substantial reduction of NMDAR-EPSC in BF cholinergic neu- 
A

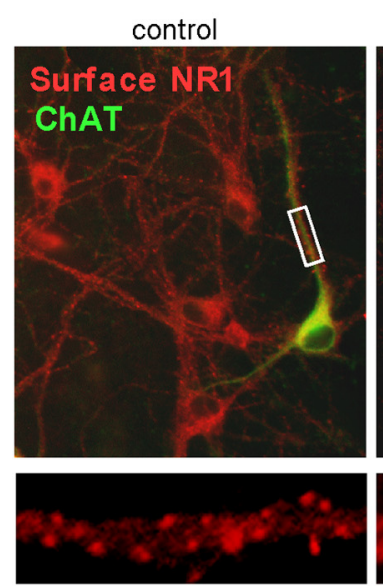

B
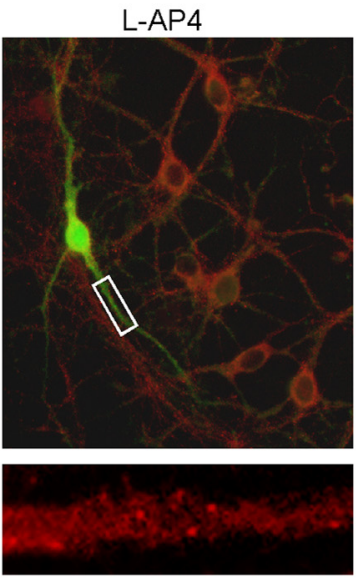
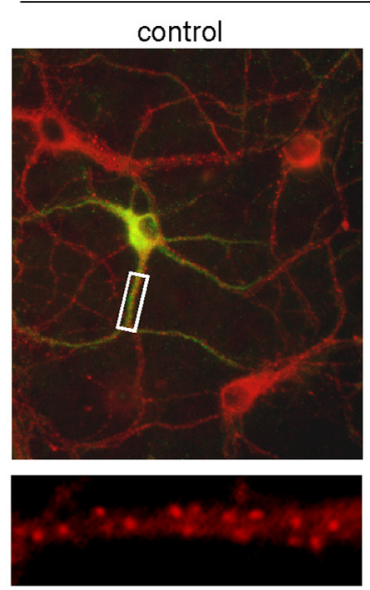

$A \beta$

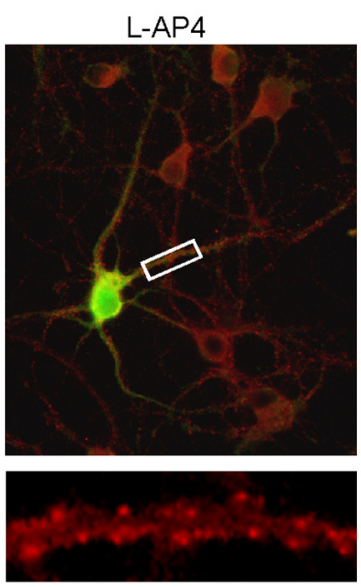

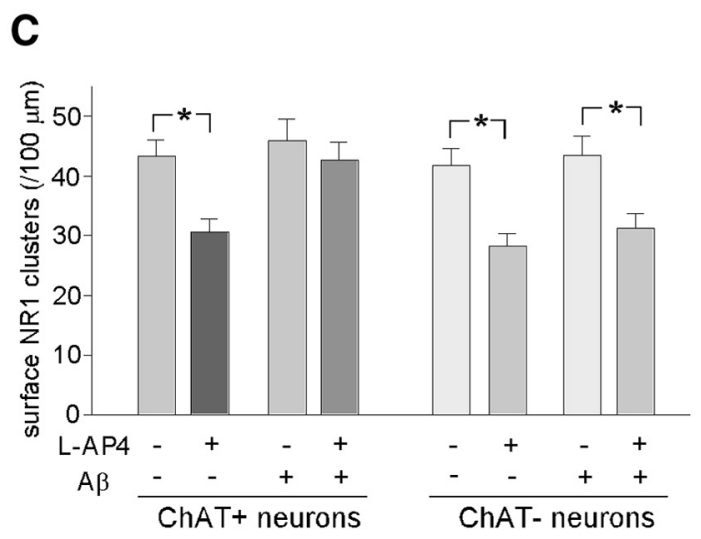

Figure 4. $A \beta$ selectively disrupted $m G$ luR7 regulation of surface NR1 in BF cholinergic neurons. $A, B$, Immunocytochemical images showing the costaining of surface NR1 (red) and ChAT (green) in cultured BF neurons treated with or without L-AP4 (200 $\mu \mathrm{m}, 15 \mathrm{~min})$ in the absence $(\boldsymbol{A})$ or presence of A $\beta$ oligomers $(1 \mu \mathrm{M}, 2 \mathrm{~h}$ preincubation; $\boldsymbol{B})$. Enlarged versions of the boxed regions of dendrites are shown beneath each of the images. C, Cumulative data (mean \pm SEM) showing the surface NR1 cluster density in BF cholinergic and noncholinergic neurons treated with or without L-AP4 in the absence or presence of $A \beta .{ }^{*} p<0.001$ (ANOVA).

rons $(71.7 \pm 3.1 \%, n=6)$. A similar effect was observed in $\mathrm{BF}$ noncholinergic neurons $(70.1 \pm 1.2 \%, n=4)$. Application of a low dose of L-AP4 $(20 \mu \mathrm{M})$, which only activates non-mGluR7 Group III mGluRs, also significantly reduced NMDAR-EPSC in BF neurons (cholinergic: $47.8 \pm 2.5 \%, n=5$; noncholinergic: $48.2 \pm 6.2 \%, n=4)$. The effect of $\mathrm{L}-\mathrm{AP} 4$ on NMDAR-EPSC in BF slices was much bigger than the effect of L-AP4 on NMDARmediated ionic currents in isolated BF neurons (a pure postsynaptic system). It suggests that Group III mGluR activation may change both presynaptic glutamate release and postsynaptic NMDA receptors in BF slices, which collectively contribute to the strong reduction of NMDAR-EPSC by L-AP4. Because EPSC only comes from the synaptic pool of NMDARs whereas ionic current comes from both synaptic and extrasynaptic pools of NMDARs, an alternative explanation for the larger effect of L-AP4 in BF slices is the better interaction of synaptic mGluRs with synaptic NMDA receptors.

To further identify presynaptic versus postsynaptic origin of Group III mGluR-induced inhibition of NMDAR-EPSC, we tested the effect of L-AP4 on coefficient of variation (CV) of synaptic currents, an index reflecting presynaptic processes (Manabe et al., 1993). $\mathrm{CV}=\mathrm{SD} /$ mean $=[(1-p) / n p]^{1 / 2}$, where $p$ is release probability and $n$ is the number of release site (Bekkers and Stevens, 1990). We found that L-AP4 (200 or $20 \mu \mathrm{M})$ significantly increased the CV of evoked NMDAR-EPSCs (Fig. 3B), suggesting that Group III mGluR activation affects presynaptic glutamate release. We further plotted the ratio of $\mathrm{CV}^{2}$ before $\left(\mathrm{CV}^{2} \mathrm{c}\right)$ and during L-AP4 application $\left(\mathrm{CV}^{2} \mathrm{~d}\right)$ against the ratio of mean NMDAR-EPSC amplitudes (EPSCd/EPSCc). Previous studies have indicated that points following on or below the diagonal (region IId) represent a purely presynaptic mechanism, whereas points above the diagonal (region IIId) could be either presynaptic or postsynaptic (Faber and Korn, 1991; Alger et al., 1996). As shown in Figure 3C, most points with a low dose of L-AP4 (20 $\mu \mathrm{M}$ ) application fell on the diagonal or region IId, whereas most points with a high dose of L-AP4 $(200 \mu \mathrm{M})$ application fell on region IIId. It suggests that activation of non-mGluR7 Group III mGluRs by L-AP4 $(20 \mu \mathrm{M})$ purely affects presynaptic release, whereas additional activation of mGluR7 by L-AP4 $(200 \mu \mathrm{M})$ induces postsynaptic changes.

Because activation of mGluR7 inhibits NMDAR-mediated synaptic transmission, we examined the impact of $\mathrm{A} \beta$ oligomers (1 $\mu \mathrm{M}, 2-4 \mathrm{~h}$ treatment) on the effect of L-AP4 on NMDAREPSCs. As shown in Figure 3D, the reduction of NMDAR-EPSCs by a high dose of L-AP4 $(200 \mu \mathrm{M})$, which activates mGluR7, was significantly smaller in $\mathrm{A} \beta$-treated $\mathrm{BF}$ cholinergic neurons (control: $71.7 \pm 3.1 \%, n=6$; $\mathrm{A} \beta$-treated: $51.8 \pm 2.6 \%, n=5 ; p<$ 0.01 , ANOVA), but not in $A \beta$-treated $\mathrm{BF}$ noncholinergic neurons. In contrast, the Group III non-mGluR7-mediated reduction of NMDAR-EPSC (induced by $20 \mu \mathrm{M}$ L-AP4) was unchanged by $\mathrm{A} \beta$ oligomers in either type of $\mathrm{BF}$ neurons. These results suggest that $\mathrm{A} \beta$ selectively impaired mGluR7 regulation of 
NMDAR-mediated postsynaptic currents in BF cholinergic neurons.

The effect of mGluR7 on surface NR1 expression is diminished by $\mathrm{A} \boldsymbol{\beta}$ in $\mathrm{BF}$ cholinergic neurons

Because mGluR7 regulates NMDAR currents via affecting NMDAR trafficking in cortical neurons ( $\mathrm{Gu}$ et al., 2012), we examined whether the $\mathrm{A} \beta$ impairment of mGluR7 regulation of NMDAR currents in $\mathrm{BF}$ cholinergic neurons is due to the $\mathrm{A} \beta$-induced loss of mGluR7 effects on surface NMDAR expression in these cells. Immunochemical staining of surface NR1 using an antibody recognizing the extracellular domain of NR1 was performed in cultured BF neurons under the nonpermeabilized condition. As shown in Figure $4 A$, application of L-AP4 $(200 \mu \mathrm{M}, 15 \mathrm{~min})$ significantly decreased the density of surface NR1 clusters (no. of clusters/100 $\mu \mathrm{m}$ ) in $\mathrm{BF}$ cholinergic neurons (control: $43.3 \pm 2.7, \mathrm{~L}-\mathrm{AP} 4: 30.6 \pm 2.2, n=30, p<$ 0.001, ANOVA; Fig. 4C). A similar effect was observed in BF noncholinergic neurons (control: $41.8 \pm 2.8, \mathrm{~L}-\mathrm{AP} 4: 28.2 \pm$ 2.2, $n=30, p<0.001$, ANOVA; Fig. $4 C$ ). Treatment with $\mathrm{A} \beta$ oligomers $(1 \mu \mathrm{M}, 2 \mathrm{~h})$ abolished the effect of L-AP4 on surface NR1 clusters in BF cholinergic neurons (Fig. $4 B$; $\mathrm{A} \beta$ : $45.9 \pm 3.6, \mathrm{~A} \beta+\mathrm{L}-\mathrm{AP} 4$ : $42.6 \pm 3.1, n=30, p>0.05$, ANOVA; Fig. $4 C)$, although it failed to alter the reducing effect of L-AP4 in BF noncholinergic neurons $(\mathrm{A} \beta$ : $43.5 \pm 3.2, \mathrm{~A} \beta+\mathrm{L}-\mathrm{AP} 4$ : $31.2 \pm 2.5, n=30, p<0.001$, ANOVA; Fig. 4C). These results suggest that mGluR7 activation decreases the level of surface NMDARs, which is disrupted by $\mathrm{A} \beta$ in $\mathrm{BF}$ cholinergic neurons.
A

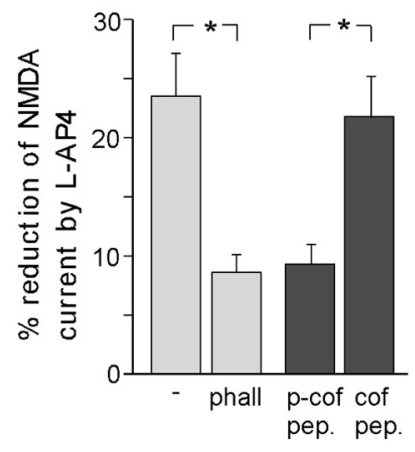

C
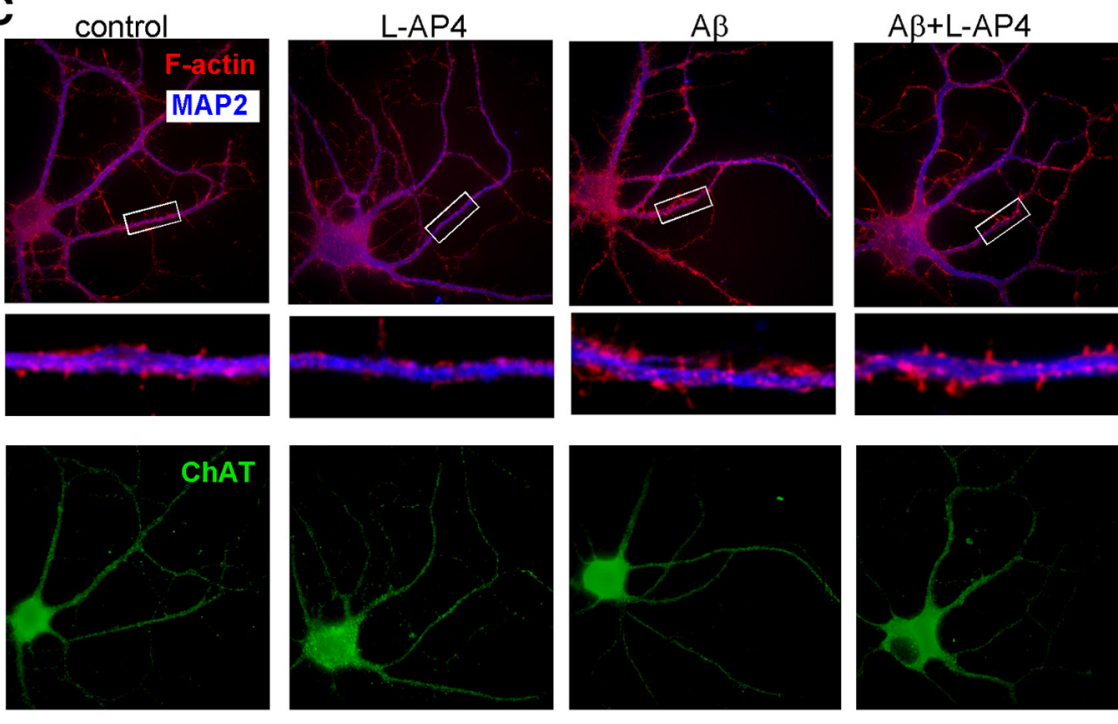

Figure 5. Actin and the major actin depolymerizing factor cofilin were involved in mGluR7 regulation of NMDAR currents, and $A \beta$ selectively disrupted mGluR7 regulation of $F$-actin in $B F$ cholinergic neurons. $A$, Cumulative data (mean $\pm S E M$ ) showing the percentage reduction of NMDAR currents by L-AP4 in the presence of various agents that interfere with actin stability, such as phalloidin $(5 \mu \mathrm{m})$ or the cofilin inhibitory peptide (p-cof pep., $200 \mu \mathrm{M}$ ) versus the negative control peptide (cof pep., $200 \mu \mathrm{m}$ ). ${ }^{*} p<0.005$ (ANOVA). $\boldsymbol{B}$, Cumulative data (mean \pm SEM) showing the F-actin cluster density in BF cholinergic and noncholinergic neurons treated with or without L-AP4 (200 $\mu \mathrm{M}, 10 \mathrm{~min})$ in the absence or presence of $A \beta$ oligomers ( $1 \mu \mathrm{M}, 2 \mathrm{~h}$ preincubation). ${ }^{*} p<0.001$ (ANOVA). C, Immunocytochemical images showing the costaining of F-actin (phalloidin, red) and MAP2 (blue) in cultured BF cholinergic neurons (ChAT ${ }^{+}$, green) with different treatments.

\section{$\mathrm{A} \boldsymbol{\beta}$ selectively disrupts $\mathrm{mGluR7}$ regulation of F-actin and increases p21-activated kinase (PAK)-mediated cofilin phosphorylation in $\mathrm{BF}$ cholinergic neurons}

How could $A \beta$ impair mGluR7 regulation of NMDR currents selectively in BF cholinergic neurons? Our previous study has shown that mGluR7 reduces NMDAR surface expression by increasing the activity of cofilin, the major actin depolymerizing factor (dos Remedios et al., 2003), and the ensuing actin depolymerization in cortical neurons (Gu et al., 2012). Similarly, we found that the effect of L-AP4 on NMDAR currents was significantly attenuated in $\mathrm{BF}$ cholinergic neurons dialyzed with the actin stabilizer phalloidin ( $5 \mu \mathrm{M}, 8.4 \pm 1.5 \%, n=8$; Fig. $5 A)$, compared with control cells $(23.5 \pm 3.6 \%, n=8)$. Phalloidin itself had no significant effect on NMDAR currents (control: $538 \pm 35$ pA, $n=8$; phalloidin: $552 \pm 41 \mathrm{pA}, n=8$ ). Because cofilin is inactivated by phosphorylation at Ser 3 and reactivated by dephosphorylation (Morgan et al., 1993), we used two peptides consisting of 1-16 residues of cofilin with or without Ser3phosphorylated (Aizawa et al., 2001; Duffney et al., 2013) to examine the involvement of cofilin. Dialysis with the p-cofilin peptide $(100 \mu \mathrm{M})$, an inhibitor of endogenous cofilin, signifi- cantly diminished the effect of L-AP4 on NMDAR currents in BF cholinergic neurons $(9.3 \pm 1.7 \%, n=9$; Fig. $5 A)$, whereas the cofilin peptide $(100 \mu \mathrm{M})$, a negative control, failed to alter the L-AP4 effect $(21.8 \pm 3.5 \%, n=8)$. The $\mathrm{p}$-cofilin or cofilin peptide itself had no significant effect on NMDAR currents (control: $534 \pm 32$ pA, $n=8$; p-cofilin peptide: $544 \pm 37$ pA, $n=9$; cofilin peptide: $526 \pm 36 \mathrm{pA}, n=8$ ). These data suggest that mGluR7 reduces NMDAR currents in BF by altering cofilin/actin signaling.

Given the actin dependence of the mGluR7 modulation, we speculated that $\mathrm{A} \beta$ might interfere with mGluR7 regulation of actin dynamics specifically in BF cholinergic neurons. To test this, we performed immunocytochemical staining of filamentous actin with phalloidin in cultured BF neurons. As shown in Figure $5 B, C$, L-AP4 treatment $(200 \mu \mathrm{M}, 10 \mathrm{~min})$ significantly reduced the density of F-actin clusters (no. of clusters/100 $\mu \mathrm{m}$ ) in BF cholinergic neurons (control: $76.5 \pm 5.8, \mathrm{~L}-\mathrm{AP} 4: 50.8 \pm 3.9, n=$ $30, p<0.001$, ANOVA). A $\beta$ treatment ( $1 \mu \mathrm{M}, 2 \mathrm{~h})$ significantly increased F-actin clusters in BF cholinergic neurons (103.8 \pm 7.6 , $n=30)$ and prevented the subsequently applied L-AP4 from reducing F-actin clusters in these neurons $(95.4 \pm 7.3, n=30)$. In 
A
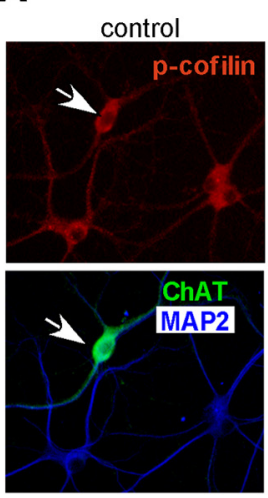
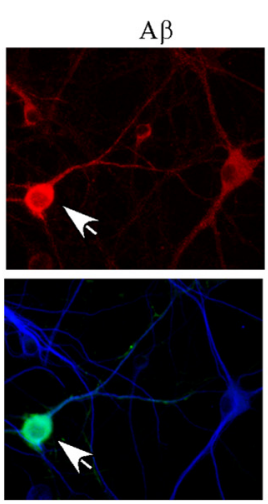

B
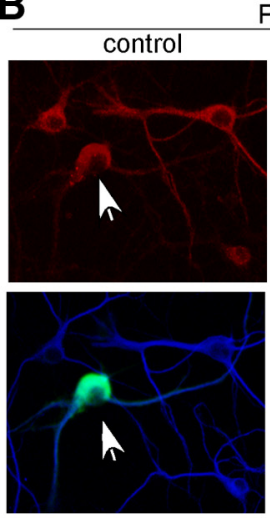

PAK18

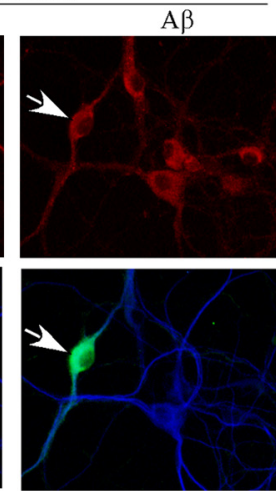

C

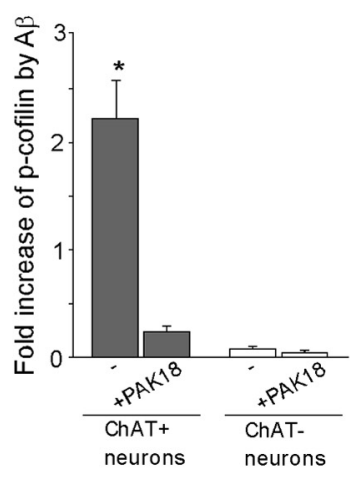

Figure 6. $A \beta$ selectively increased PAK-mediated cofilin phosphorylation in BF cholinergic neurons. $\boldsymbol{A}, \boldsymbol{B}$, Immunocytochemical images showing the costaining of phosphorylated (inactive) cofilin (p-cofilin, red), ChAT (green), and MAP2 (blue) in cultured BF neurons treated with or without A $\beta(1 \mu \mathrm{m}, 2 \mathrm{~h})$ in the absence $(\boldsymbol{A})$ or presence (B) of TAT-PAK18 (10 $\mu \mathrm{m})$, a PAK inhibitory peptide. Arrows point to $B F$ cholinergic neurons. C, Cumulative data (mean \pm SEM) showing the increase of the intensity of $p$-cofilin staining by $A \beta$ in $B F$ cholinergic and noncholinergic neurons treated with or without PAK18. ${ }^{*} p<0.001$ (ANOVA).

contrast, $\mathrm{A} \beta$ treatment had no significant effect on F-actin clusters in BF noncholinergic neurons (control: $70.1 \pm 5.4, \mathrm{~A} \beta$ : $73.6 \pm 5.1, n=30)$ and failed to prevent the reducing effect of L-AP4 in these neurons $(49.8 \pm 3.3, n=30)$. These results suggest that $\mathrm{A} \beta$ selectively affects the actin assembly and its regulation by mGluR7 in BF cholinergic neurons, which could underlie the specific impairment of mGluR7 regulation of NMDR currents in these cells by $\mathrm{A} \beta$.

How does $\mathrm{A} \beta$ selectively affect the actin integrity in BF cholinergic neurons? Given the key role of cofilin in regulating actin depolymerization, we speculated that $\mathrm{A} \beta$ might selectively affect cofilin activity in $\mathrm{BF}$ cholinergic neurons. Consistent with this, $\mathrm{A} \beta$ treatment $(1 \mu \mathrm{M}, 2 \mathrm{~h})$ induced a strong increase of the Ser3phosphorylated (inactive) cofilin in BF cholinergic neurons (Fig. $6 A ; 2.23 \pm 0.35$-fold increase, $n=20$; Fig. $6 C$ ), but not in noncholinergic neurons (Fig. $6 A ; 0.08 \pm 0.02$-fold increase, $n=15$; Fig. $6 C$ ). The level of total cofilin was not altered by $\mathrm{A} \beta$ treatment (data not shown). It suggests that $\mathrm{A} \beta$ decreased the actindepolymerizing activity of cofilin selectively in BF cholinergic neurons, which could antagonize the mGluR7-induced increase of cofilin activity (Gu et al., 2012).

We further examined how $\mathrm{A} \beta$ increased cofilin phosphorylation in BF cholinergic neurons. One of the key upstream proteins that regulates the phosphorylation and activity of cofilin is PAK (Edwards et al., 1999). It has been found that PAK signaling defects potentially play a causal role in cognitive deficits in AD (Zhao et al., 2006). To examine the involvement of PAK in A $\beta$ increase of cofilin phosphorylation, we treated BF cultures with a PAK inhibitor, PAK18, which is a peptide against a specific PAK inhibitory domain coupled to a cell permeant TAT peptide sequence (Zhao et al., 2006; Duffney et al., 2013). As shown in Figure $6 B$, inhibiting PAK with PAK18 $(10 \mu \mathrm{M})$ treatment prevented $A \beta$ from increasing cofilin phosphorylation in BF cholinergic neurons $(0.25 \pm 0.05$-fold increase, $n=10$; Fig. $6 C)$. It suggests that $\mathrm{A} \beta$ affects the actin dynamics via the $\mathrm{PAK} /$ cofilin pathway.

\section{$\mathrm{A} \beta$ increases PAK activity in BF cholinergic neurons through} a $75^{\mathrm{NTR}}$-dependent mechanism

Because $\mathrm{A} \beta$ increased cofilin phosphorylation selectively in $\mathrm{BF}$ cholinergic neurons, we further examined whether $\mathrm{A} \beta$ treatment selectively induced PAK activation in these cells. It has been shown that Thr423 is a critical phosphorylation site in the PAK activation process (Gatti et al., 1999; Zenke et al., 1999). Thus, we examined the effect of $\mathrm{A} \beta$ oligomers on ${ }^{\mathrm{Th}}{ }^{2}{ }^{23} \mathrm{p}$-PAK staining in BF cultures. As shown in Figure $7 A$, the p-PAK level was selectively increased by $\mathrm{A} \beta$ treatment in $\mathrm{ChAT}^{+}$neurons $(2.44 \pm$ 0.38 -fold increase, $n=30$; Fig. $7 C$ ), which may explain the selective increase of $\mathrm{p}$-cofilin by $\mathrm{A} \beta$ in these cells. In contrast, $\mathrm{A} \beta$ treatment had no significant effect on p-PAK in BF noncholinergic neurons (Fig. 7A). The level of total PAK was not altered by $\mathrm{A} \beta$ treatment (data not shown).

How does $\mathrm{A} \beta$ selectively activate PAK in BF cholinergic neurons? We speculated that it might be due to some protein selectively expressed in these cells. One candidate is the p75 neurotrophin receptor $\left(\mathrm{p} 75^{\mathrm{NTR}}\right)$, which is highly enriched in cholinergic neurons of adult animals (Batchelor et al., 1989; Gibbs et al., 1989). Several studies show that $\mathrm{p} 75^{\mathrm{NTR}}$ is one of the membrane binding partners for A $\beta$ (Yaar et al., 1997; Perini et al., 2002; Costantini et al., 2005). Thus, it is possible that $A \beta$ binds to p $75^{\text {NTR }}$ in BF cholinergic neurons, leading to the activation of PAK. To test this, we treated BF cultures with a neutralizing antibody to the extracellular ligand binding domain of $\mathrm{p} 75^{\mathrm{NTR}}$ to block the activation of p75 NTR signaling (Baldwin and Shooter, $1995)$, or with an antisense oligonucleotide against $\mathrm{p} 75^{\mathrm{NTR}}\left(5^{\prime}\right.$ ACCTGCCCTCCTCATTGCA-3') (Florez-McClure et al., 2004) to ablate the expression of $\mathrm{p} 75^{\mathrm{NTR}}$ in cholinergic neurons, and examined the effect of $A \beta$ on $\mathrm{p}$-PAK. As shown in Figure $7 B$, the p $75^{\text {NTR }}$ antibody prevented $A \beta$-induced PAK phosphorylation (activation) in BF cholinergic neurons $(0.16 \pm 0.05$-fold increase, $n=20$; Fig. $7 C$ ). Moreover, in p $75^{\mathrm{NTR}}$ antisense-treated BF cholinergic neurons (Fig. $7 B$ ), $A \beta$ failed to induce PAK phosphorylation $(0.11 \pm 0.06$-fold increase, $n=20$; Fig. $7 C)$. The selective expression of $\mathrm{p} 75^{\mathrm{NTR}}$ in BF cholinergic neurons and its specific loss in $\mathrm{p} 75^{\mathrm{NTR}}$ antisense-treated BF cultures were also verified (Fig. 7D).

We further tested whether $\mathrm{p} 75^{\mathrm{NTR}}$ was involved in the impact of $\mathrm{A} \beta$ on mGluR7 regulation of NMDARs in BF cholinergic neurons. As shown in Figure $7 E, F$, incubation of $\mathrm{A} \beta$ oligomer significantly impaired the effect of L-AP4 on NMDAR currents (untreated: $28.0 \pm 1.9 \%, n=7 ; \mathrm{A} \beta$-treated: $12.9 \pm 0.9 \%, n=10$; $p<0.001$ ), which was completely blocked by the pretreatment of p75 ${ }^{\mathrm{NTR}}$ neutralizing antibody $\left(\mathrm{p} 75^{\mathrm{NTR}} \mathrm{ab}+\mathrm{A} \beta\right.$-treated: $25.3 \pm$ $1.2 \%, n=10$ ), suggesting that $\mathrm{A} \beta$ impairs mGluR7 effects via $\mathrm{p} 75^{\mathrm{NTR}}$ in BF cholinergic neurons. 


\section{Activation of mGluR7 protects $\mathrm{BF}$ neurons from NMDA-induced excitotoxicity, which is selectively impaired by $\mathrm{A} \boldsymbol{\beta}$ in BF cholinergic neurons}

What is the functional implication of the mGluR7 downregulation of NMDAR currents and its selective impairment by $\mathrm{A} \beta$ in $\mathrm{BF}$ cholinergic neurons? Is it potentially linked to the selective degeneration of $\mathrm{BF}$ cholinergic neurons at the early stage of $\mathrm{AD}$ ? To address these questions, we examined the protective role of Group III mGluRs against NMDAR-mediated excitotoxicity, one of the pathophysiological mechanisms underlying AD (Doraiswamy, 2003; Cosman et al., 2007). We also examined whether $A \beta$ selectively impaired mGluR-mediated protection in BF cholinergic neurons.

Excitotoxicity was modeled by treating BF cultures with NMDA (50 $\mu \mathrm{M}, 10 \mathrm{~min})$. Cultures were washed and returned to regular medium after treatment. Twentyfour hours later, cells were collected for immunocytochemical experiments. Survival neurons were detected with antiMAP2, and apoptotic cell death was indicated by shrunk and condensed nucleus in PI staining (Ankarcrona et al., 1995; Bonfoco et al., 1995). As shown in Figure $8 A, B$, NMDA treatment induced remarkable apoptosis in $\mathrm{BF}$ cholinergic and noncholinergic neurons, as indicated by significantly decreased number of $\mathrm{MAP}^{+}{ }^{+}$or $\mathrm{ChAT}^{+}$neurons and significantly increased number of cells with shrunk and condensed nucleus in PI staining (control: $4.4 \pm 1.1 \%$ apoptosis; NMDA-treated: $76.3 \pm 11.7 \%$ apoptosis). L-AP4 treatment $(200 \mu \mathrm{M}, 15$ min preincubation) significantly protected cholinergic and noncholinergic neurons from NMDA-induced cell death, as indicated by increased number of $\mathrm{MAP}^{+}{ }^{+}$or $\mathrm{ChAT}^{+}$ neurons and reduced number of cells with condensed PI staining (Fig. 8C; $34.5 \pm$ $6.3 \%$ apoptosis). Treatment with $\mathrm{A} \beta$ oligomers (1 $\mu \mathrm{M}, 2 \mathrm{~h}$ before L-AP4 application) selectively impaired the protective effect of L-AP4 in cholinergic neurons but not in noncholinergic neurons, as indicated by the increased number of $\mathrm{MAP} 2^{+} / \mathrm{ChAT}^{-}$neurons, but not $\mathrm{ChAT}^{+}$ neurons (Fig. $8 D$ ). Treatment with $\mathrm{A} \beta$ oligomers $(1 \mu \mathrm{M}, 24 \mathrm{~h})$ alone did not induce toxicity in BF cultures (data not shown).

We counted the number of surviving cholinergic $\left(\mathrm{MAP}^{+} / \mathrm{ChAT}^{+}\right)$and noncholinergic neurons $\left(\mathrm{MAP}^{+} / \mathrm{ChAT}^{-}\right.$) $24 \mathrm{~h}$ after $10 \mathrm{~min}$ NMDA treatment (Fig. $8 E)$. We found that $21.1 \pm 4.3 \%$ of $\mathrm{BF}$ cholinergic neurons and $20.3 \pm 3.8 \%$ of
A
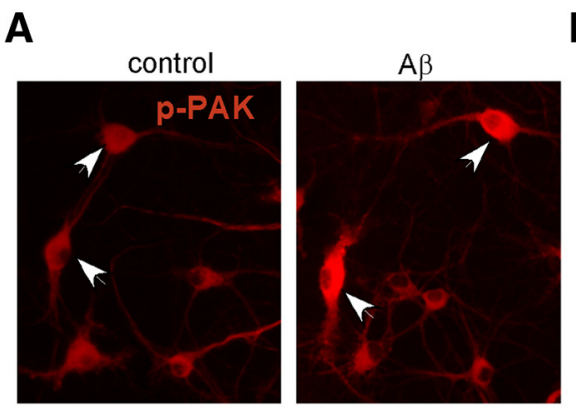

B P75NTR antibody

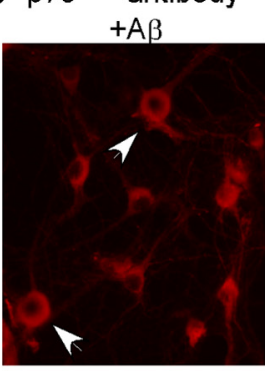

p75NTR antisense
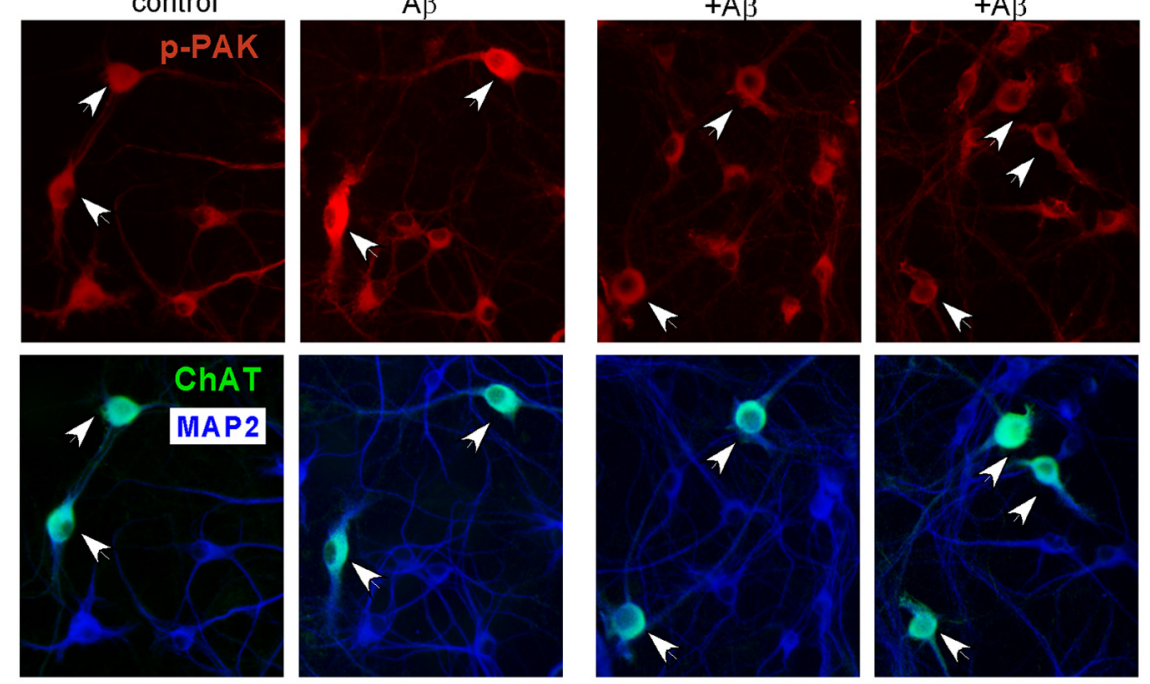

C

D
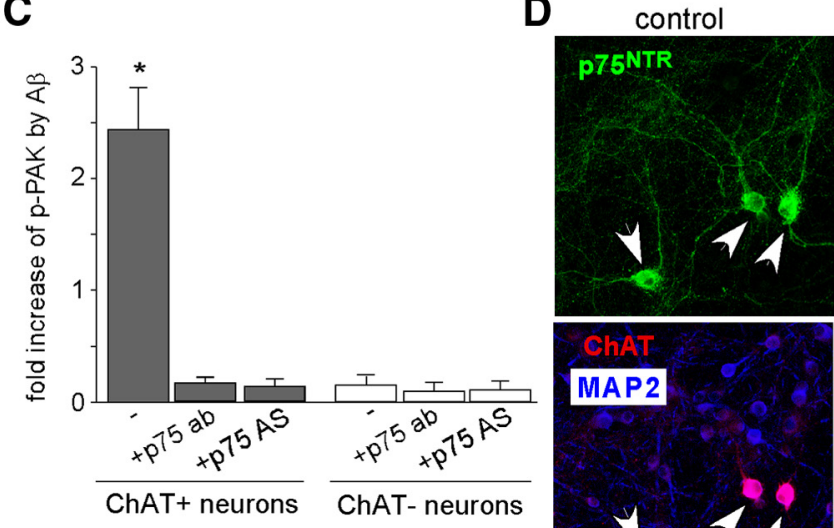

p75NTR AS-treated
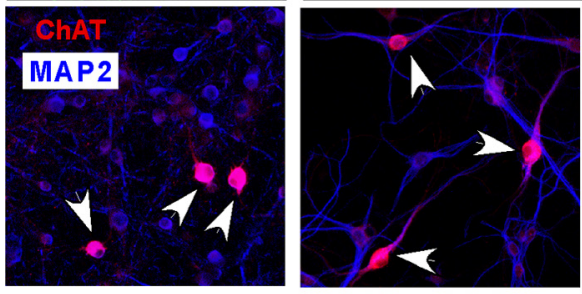

E

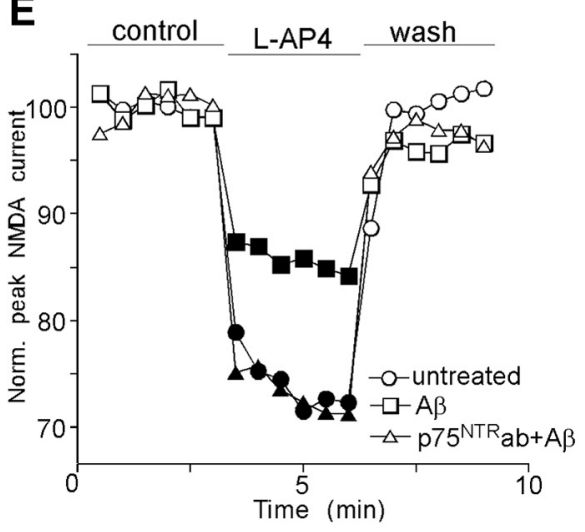

$\mathbf{F}$

$\square$ untreated

$\square \mathrm{A} \beta$-treated

- $75^{\mathrm{NTR}} \mathrm{ab}+\mathrm{A} \beta$-treated

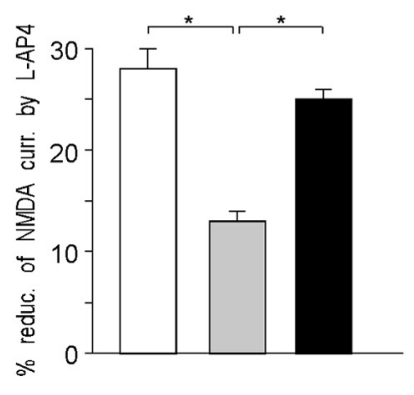

Figure 7. $A \beta$ selectively increased PAK activity in $B F$ cholinergic neurons through a mechanism involving p $75^{\mathrm{NTR}} \cdot \mathbf{A}, \boldsymbol{B}, \mathrm{Immu}$ nocytochemical images showing the costaining of phosphorylated PAK (p-PAK, red), ChAT (green), and MAP2 (blue) in cultured BF neurons treated with or without $A \beta$ oligomers $(1 \mu \mathrm{m}, 2 \mathrm{~h})$ in the absence $(A)$ or presence of $p 75^{\text {NTR }}$ neutralizing antibody (2 $\mu \mathrm{g} / \mathrm{ml}$, added at $15 \mathrm{~min}$ before $A \beta$ treatment, $\boldsymbol{B})$ or p $75^{\mathrm{NTR}}$ antisense oligonucleotide $(5 \mu \mathrm{M}$, added 5 d before $A \beta$ treatment; $\boldsymbol{B})$. C, Cumulative data (mean \pm SEM) showing the fold increase of $\mathrm{p}$-PAK by A $\beta$ in cholinergic and noncholinergic neurons treated with or without $p 75^{\mathrm{NTR}}$ antibody (ab) or p $75^{\mathrm{NTR}}$ antisense (AS). D, Immunocytochemical images showing the costaining of $\mathrm{p} 75^{\mathrm{NTR}}$ (green), ChAT (red), and MAP2 (blue) in BF cultures treated with or without p $75^{\mathrm{NTR}}$ antisense oligonucleotide. Arrows point to $\mathrm{ChAT}^{+}$neurons. $E$, Plot of normalized peak NMDAR currents showing the effect of L-AP4 $(200 \mu \mathrm{m})$ in cultured BF cholinergic neurons either untreated or treated with oligomeric $A \beta(1 \mu \mathrm{m}, 2 \mathrm{~h})$ or $A \beta$ plus p $75^{\mathrm{NTR}}$ antibody $(2 \mu \mathrm{g} / \mathrm{ml}$, added at $15 \mathrm{~min}$ before $A \beta$ treatment). $F$, Cumulative data (mean \pm SEM) showing the percentage reduction of NMDAR currents by L-AP4 in BF cholinergic neurons under different treatments. ${ }^{*} p<0.001$ (ANOVA). 

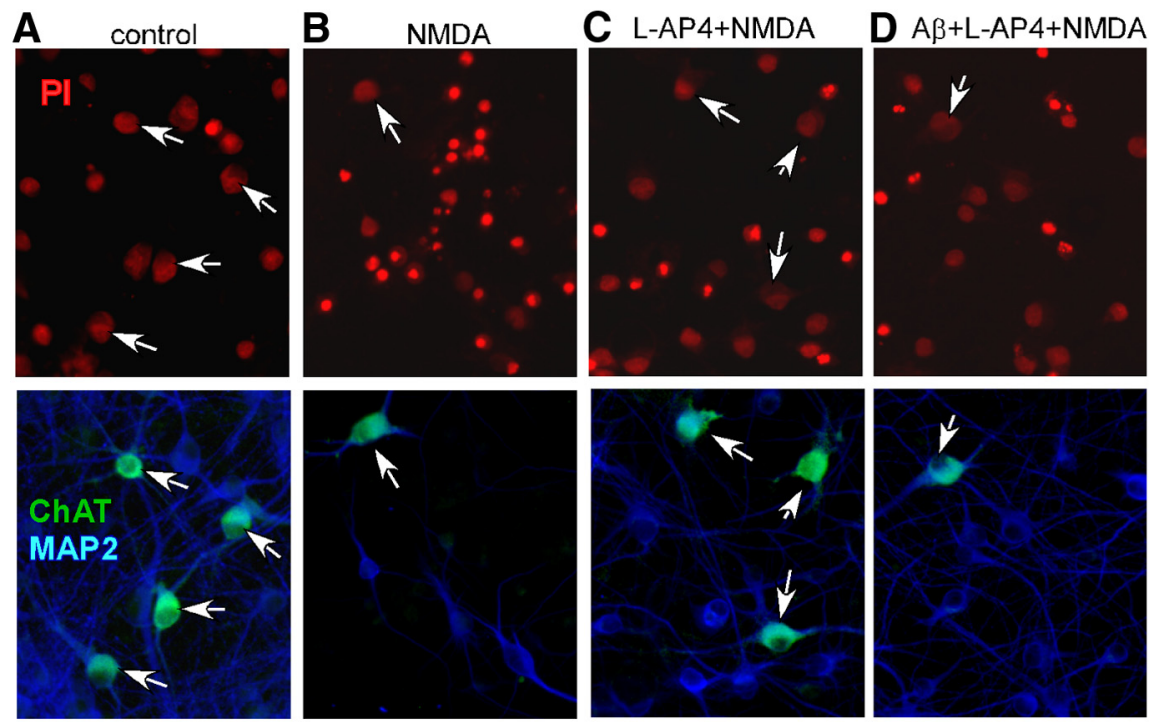

$\mathbf{E}$

\section{$\mathbf{F}$}
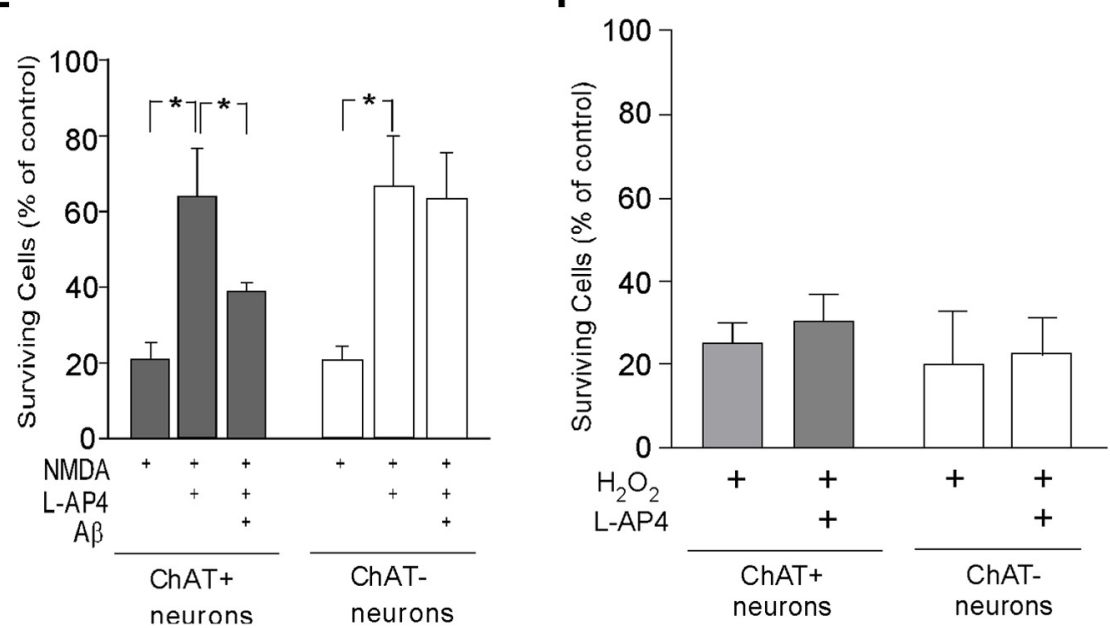

Figure 8. A $\beta$ selectively disrupted mGluR7 protection of BF cholinergic neurons against NMDA excitotoxicity. $\boldsymbol{A}-\boldsymbol{D}$, Immunocytochemical images showing the costaining of ChAT (green), MAP2 (blue), and PI (a nuclear marker, red) in BF cultures untreated (control, $\boldsymbol{A}$ ) or treated with NMDA (50 $\mu \mathrm{m}, 10 \mathrm{~min}, \boldsymbol{B})$, NMDA plus L-AP4 (200 $\mu \mathrm{m}$, added at $15 \mathrm{~min}$ before NMDA, ), or NMDA + $\mathrm{L}-\mathrm{AP} 4+\mathrm{A} \beta(1 \mu \mathrm{M}, \mathrm{A} \beta$ added at $2 \mathrm{~h}$ before L-AP4, D). Neurons were collected $24 \mathrm{~h}$ later for staining. Surviving cells are positive for MAP2 staining. Surviving cholinergic neurons are also positive for ChAT staining. Arrows point to $\mathrm{ChAT}^{+}{ }^{+}$neurons. Apoptotic cell death is detected with the shrunk and condensed nucleus in PI staining. $\boldsymbol{E}$, Cumulative data (mean \pm SEM) showing the percentage of surviving BF cholinergic (MAP2 ${ }^{+} / \mathrm{ChAT}^{+}$) and noncholinergic (MAP2 ${ }^{+} / \mathrm{ChAT}^{-}$) neurons under different treatments ${ }^{*} p<0.001$ (ANOVA). $\boldsymbol{F}$, Cumulative data (mean \pm SEM) showing the percentage of surviving cholinergic $\left(\mathrm{MAP2}^{+} / \mathrm{p} 75^{\mathrm{NTR}+}\right.$ ) and noncholinergic (MAP2 ${ }^{+} / \mathrm{p} 75^{\mathrm{NTR}-}$ ) neurons in BF cultures treated with $\mathrm{H}_{2} \mathrm{O}_{2}(100 \mu \mathrm{M}, 10 \mathrm{~min})$ or $\mathrm{H}_{2} \mathrm{O}_{2}$ plus L-AP4 (200 $\mu \mathrm{M}$, added at 15 min before $\mathrm{H}_{2} \mathrm{O}_{2}$ ).

noncholinergic neurons remained alive. L-AP4 treatment significantly promoted cell survival in both cholinergic $(63.8 \pm 12.7 \%$ survival) and noncholinergic neurons (66.9 $\pm 13.1 \%$ survival). $\mathrm{A} \beta$ treatment selectively disrupted the protective effect of L-AP4 in cholinergic neurons ( $38.5 \pm 6.1 \%$ survival), but not in noncholinergic neurons $(63.3 \pm 12.3 \%$ survival).

We further examined whether mGluR7 protected BF cholinergic neurons against oxidative stress produced by $\mathrm{H}_{2} \mathrm{O}_{2}$, an NMDARindependent insult. BF cultures were treated with $\mathrm{H}_{2} \mathrm{O}_{2}(100 \mu \mathrm{M}$, $10 \mathrm{~min}$ ) and returned to regular medium after treatment (Whittemore et al., 1995). Twenty-four hours later, cells were subjected to immunocytochemical staining of p $75^{\mathrm{NTR}}$, MAP2, and PI. As shown in Figure $8 F, \mathrm{H}_{2} \mathrm{O}_{2}$ treatment induced significant apoptosis in $\mathrm{BF}$ neurons, which was not rescued by L-AP4 treatment $\left(\mathrm{H}_{2} \mathrm{O}_{2}: 19.7 \pm 12.5 \%\right.$ survival; $\mathrm{H}_{2} \mathrm{O}_{2}+$ L-AP4: $21.5 \pm 9.3 \%$ sur- vival). Furthermore, the number of surviving cholinergic neurons $\left(\mathrm{MAP}^{+} /\right.$ p $75^{\mathrm{NTR}+}$ ) after $\mathrm{H}_{2} \mathrm{O}_{2}$ treatment was not changed by L-AP4 treatment $\left(\mathrm{H}_{2} \mathrm{O}_{2}\right.$ : $24.6 \pm 3.0 \%$ survival; $\mathrm{H}_{2} \mathrm{O}_{2}+$ L-AP4: $29.9 \pm 4.2 \%$ survival). It suggests that mGluR7 activation does not protect BF neurons against NMDAR-independent oxidative stress.

Next, we evaluated the protective role of mGluR7 on excitotoxicity and its impairment by $\mathrm{A} \beta$ in a more physiological setting in vivo. NMDA (60 mM, $1 \mu \mathrm{l})$ was sterotaxically injected to the NBM region (a key component of BF) of WT or APP transgenic mice to induce excitotoxicity. L-AP4 $(50 \mathrm{mg} / \mathrm{kg})$ was intraperitoneally injected at $1 \mathrm{~h}$ before NMDA injection. One day later, animals were sacrificed and BF slices were stained for ChAT to label surviving cholinergic neurons. As shown in Figure $9 A-D$, compared with the shamoperated control group, NMDA injection caused a significant loss of NBM cholinergic $\left(\mathrm{ChAT}^{+}\right)$neurons in both WT mice $(28.6 \pm 10.7 \%$ survival $)$ and APP transgenic mice $(25.7 \pm 9.4 \%$ survival). Administration of L-AP4 significantly promoted the survival of NBM cholinergic neurons in WT mice $(85.1 \pm 8.6 \%$ survival), but not in $A P P$ transgenic mice (30.3 $\pm 9.3 \%$ survival).

To examine the role of $A \beta$ in the impaired mGluR7 protection of BF cholinergic neurons against excitotoxicity in $A P P$ transgenic mice, we injected (i.p.) A $\beta$ antibody $(3 \mathrm{mg} / \mathrm{kg})$ to neutralize $A \beta$, which has been demonstrated to reverse AD-like behavioral deficits (Hartman et al., 2005; Basi et al., 2010). As shown in Figure $9 E, F$, administration of $A \beta$ antibody significantly rescued the protective effects of L-AP4 on NMDA-induced excitotoxicity in NBM cholinergic neurons of APP transgenic mice (L-AP4 + NMDA: $29.9 \pm 6.7 \%$ survival; $\mathrm{A} \beta \mathrm{ab}+\mathrm{L}-\mathrm{AP} 4+$ NMDA: $74.0 \pm 12.3 \%$ survival). Furthermore, injection (i.v.) of TAT-PAK18 (0.6 $\mathrm{pmol} / \mathrm{g}$ ) to $A P P$ transgenic mice partially rescued NBM cholinergic neurons against excitotoxicity (Fig. $9 G, H$; NMDA: $25.8 \pm 8.0 \%$ survival; PAK18 + NMDA: $58.1 \pm 8.3 \%$ survival). It suggests that $\mathrm{A} \beta$ prevents mGluR7 from protecting NBM cholinergic neurons against NMDA-induced excitotoxicity via PAK in vivo.

Together, these results suggest that mGluR7 has a protective role against NMDA excitotoxicity, which is selectively impaired by $\mathrm{A} \beta$ in $\mathrm{BF}$ cholinergic neurons. It provides a potential mechanism for the $\mathrm{A} \beta$-induced disruption of calcium homeostasis (Mattson et al., 1993), which might contribute to the selective degeneration of $\mathrm{BF}$ cholinergic neurons in $\mathrm{AD}$.

\section{Discussion}

BF cholinergic neurons provide $70 \%$ cholinergic innervations to the whole cortical area (Bigl et al., 1982; Rye et al., 1984). A 
A

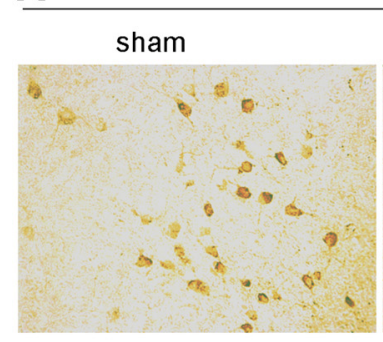

B
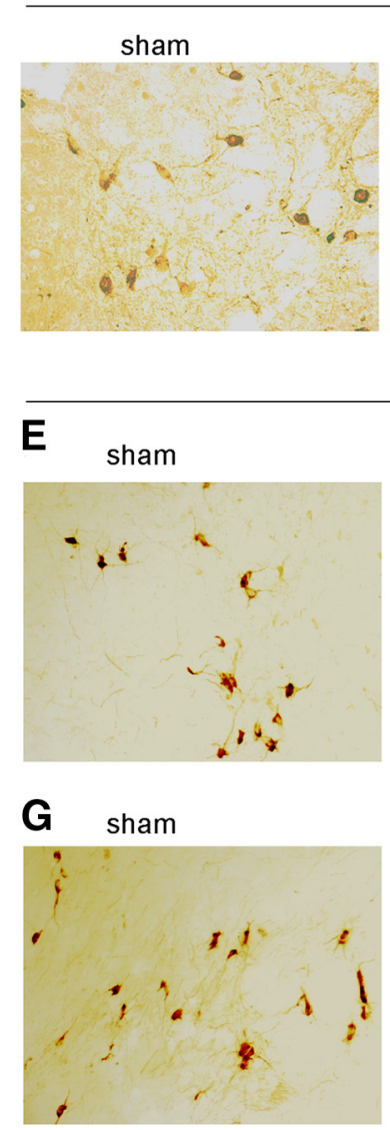

WT

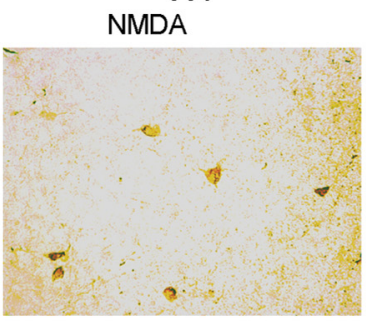

APP

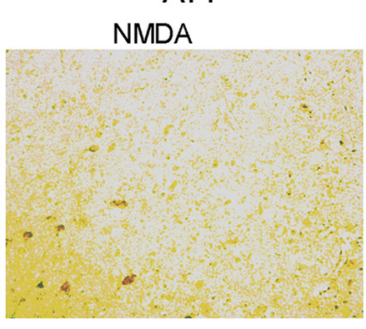

APP

L-AP4+NMDA

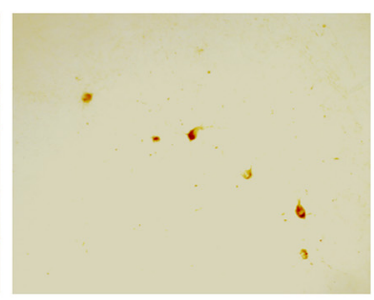

NMDA

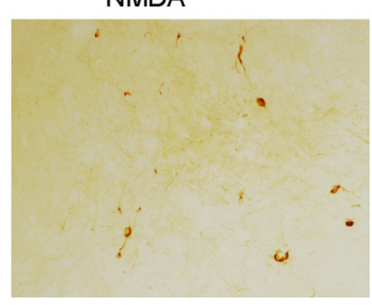

L-AP4 +NMDA

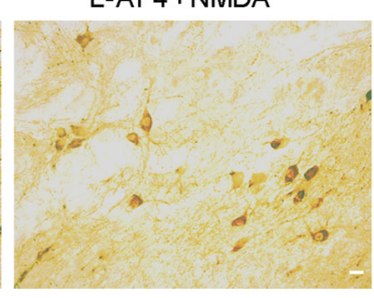

D

\section{。}

\section{F}

$A \beta a b+L-A P 4+N M D A$
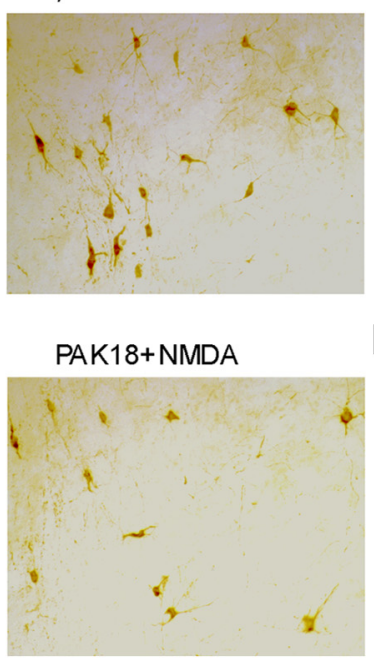
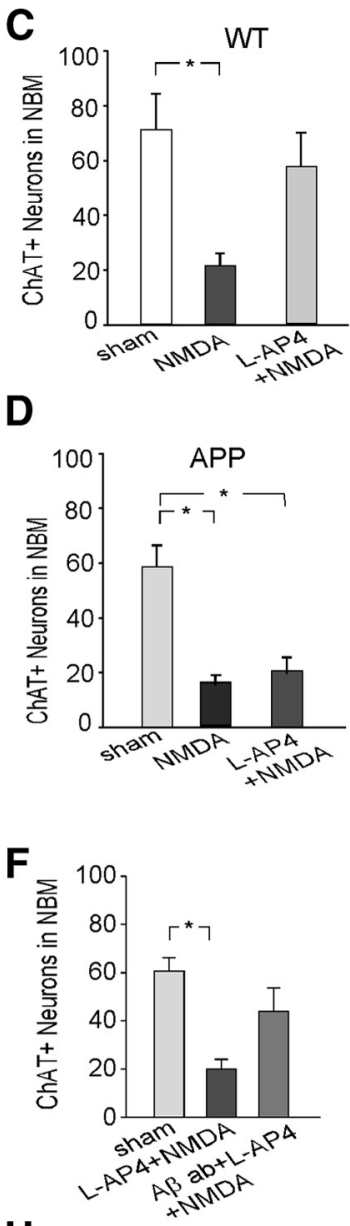

$\mathrm{H}$

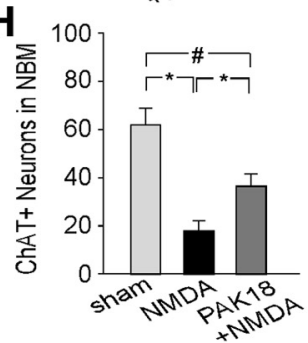

Figure 9. The disrupted mGluR7 protection of BF cholinergic neurons against NMDA excitotoxicity in APP transgenic mice was restored by A $\beta$ neutralization or PAK inhibition. $\boldsymbol{A}, \boldsymbol{B}$, Immunohistochemical images showing the staining of ChAT in BF slices from WT $(\boldsymbol{A})$ or APP $(\boldsymbol{B})$ mice. Animals were sterotaxically injected with NMDA (60 mM, $1 \mu$ l) to NBM. Some animals were intraperitonelly injected with $\mathrm{L}-\mathrm{AP4}(50 \mathrm{mg} / \mathrm{kg})$ at $1 \mathrm{~h}$ before NMDA injection. Sham-operated animals were used as controls. C, $D$, Cumulative data (mean \pm SEM) showing the number of ChAT ${ }^{+}$ neurons in NBM from WT $(\boldsymbol{C})$ or APP $(\boldsymbol{D})$ mice under different treatments. Data were the average from three mice in each condition. ${ }^{*} p<0.001$ (ANOVA). $\boldsymbol{E}, \boldsymbol{F}$, Immunohistochemical images $(\boldsymbol{E})$ and cumulative data $(\boldsymbol{F})$ showing NBM ChAT ${ }^{+}$neurons in APP transgenic mice administered without or with $A \beta$ antibody $\left(A \beta\right.$ ab, $3 \mathrm{mg} / \mathrm{kg}$, i.p., $24 \mathrm{~h}$ before $\mathrm{L}-\mathrm{AP} 4$ and NMDA injection). ${ }^{*} p<0.01$ (ANOVA). $\mathbf{G}, \boldsymbol{H}$, Immunohistochemical images $(\boldsymbol{G})$ and cumulative data $(\boldsymbol{H})$ showing NBM ChAT ${ }^{+}$neurons in $A P P$ transgenic mice without or with the injection of TAT-PAK18 $(0.6 \mathrm{pmol} / \mathrm{g}$, i.v., $1 \mathrm{~h}$ before NMDA injection). ${ }^{*} p<0.01$ (ANOVA). ${ }^{*} p<0.05$ (ANOVA).

selective degeneration of BF cholinergic neurons was observed in AD patients several decades ago (Perry et al., 1978; Whitehouse et al., 1982; Coyle et al., 1983). Since then, numerous studies have suggested a close association between the loss of BF cholinergic neurons and cognitive impairments in aged people and $\mathrm{AD}$ patients (McGeer et al., 1984; Vogels et al., 1990; Swaab et al., 1994; Winkler et al., 1995). However, it remains unclear how BF cholinergic neurons are selectively lost at the early stage of $\mathrm{AD}$. The tense glutamatergic innervations (Mesulam and Mufson, 1984; Zaborszky et al., 1997) and the vulnerability to cytotoxic effects of glutamate analogues (Wenk and Willard, 1998) suggest that BF cholinergic neurons may degenerate due to aberrant glutamatergic signaling. Metabotropic glutamate receptors have been found to play an important role in regulating neuronal excitability and synaptic plasticity, and dysfunction of mGluRs in specific brain regions have been implicated in various disorders (Baskys, 1992; Conn and Pin, 1997; Gubellini et al., 2004). In this study, we have found that activation of Group III mGluRs, particularly mGluR7, suppresses NMDAR currents and surface expression in BF cholinergic neurons, which is selectively impaired by $\mathrm{A} \beta$. Given the important role of glutamate excitotoxicity in AD (Doble, 1999, Cummings, 2004), this $\mathrm{A} \beta$-induced selective disruption of mGluR7 downregulation of NMDAR function in BF cholinergic neurons could contribute significantly to their selective degeneration in $\mathrm{AD}$ conditions. Consistent with this notion, we have found that the protective effect of mGluR7 against NMDA- 


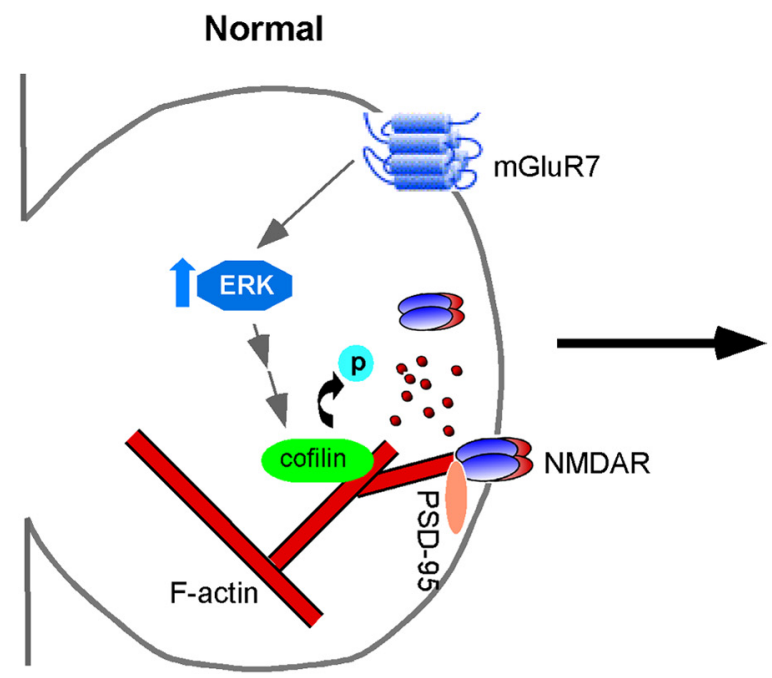

BF non-cholinergic and
cholinergic neurons

mGluR7 reduces NMDAR currents and NMDA excitotoxicity

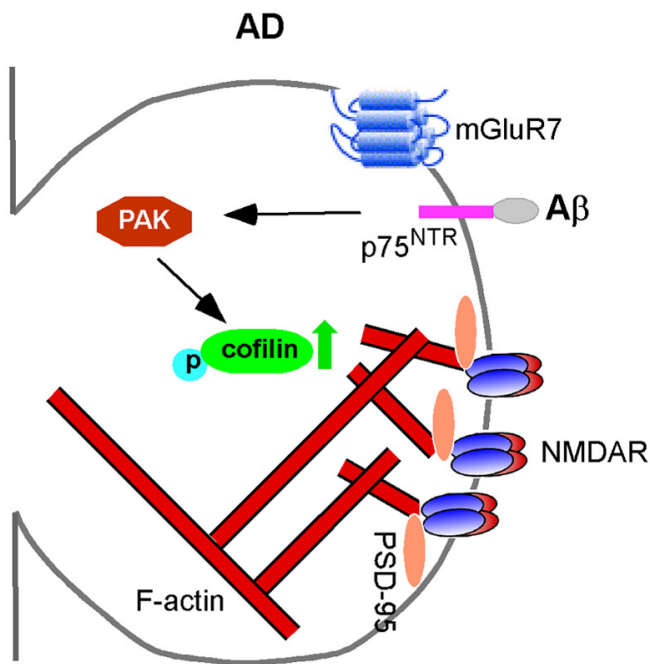

BF cholinergic neurons

Figure 10. A schematic model illustrating $A \beta$ impairment of mGluR7 regulation of NMDAR signaling in BF cholinergic neurons. Activation of mGluR7 in BF neurons triggers the increase of cofilin activity by decreasing its phosphorylation, leading to the increased actin deploymerization, which results in the reduction of NMDAR surface expression and the attenuation of NMDAR-mediated excitotoxicity. $A \beta$, by interacting with $p 75^{\text {NTR }}$ in BF cholinergic neurons, causes the selective increase of PAK activity, leading to the inactivation of cofilin by increasing its phosphorylation. Consequently, actin depolymerization is reduced, which results in the impaired mGluR7 downregulation of NMDARs and the loss of mGluR7 protection against excitotoxicity in these neurons.

induced neuronal death is selectively attenuated by $\mathrm{A} \beta$ in $\mathrm{BF}$ cholinergic neurons.

Electron microscopy studies have revealed that mGluR7, in addition to the presynaptic presence, is also postsynaptically distributed in various regions (Brandstätter et al., 1996; Kinzie et al., 1997; Kosinski et al., 1999), suggesting that mGluR7 may have postsynaptic functions. Because of the pharmacological profile of mGluRs, previous physiological studies on the role of Group III mGluRs, especially mGluR7 (a low affinity receptor), in synaptic transmission have commonly used high doses $(500-1000 \mu \mathrm{M})$ of L-AP4 (Gereau and Conn, 1995; Pelkey et al., 2006; Martín et al., 2007; Ayala et al., 2008). By using dissociated neurons, a pure postsynaptic system, we have revealed the postsynaptic action of mGluR7 on NMDAR currents. Our analysis of CV of synaptic currents, an index reflecting presynaptic processes (Faber and Korn, 1991; Manabe et al., 1993; Alger et al., 1996), further suggests that activation of non-mGluR7 Group III mGluRs by L-AP4 $(20 \mu \mathrm{M})$ purely affects presynaptic release, whereas additional activation of mGluR7 by L-AP4 $(200 \mu \mathrm{M})$ induces postsynaptic changes. Thus, unlike the presynaptically located mGluRs, which inhibit transmitter release and therefore affect the response of many postsynaptic receptor subtypes, the postsynaptic modulation of NMDARs by mGluR7 provides a way for more specific regulation. Interestingly, only the postsynaptic effect of mGluR7 on NMDAR-mediated ionic or synaptic currents is selectively impaired by $\mathrm{A} \beta$ in $\mathrm{BF}$ cholinergic neurons, suggesting that this effect is pathologically relevant. The selective disruption of mGluR7 protection against NMDA excitotoxicity by $A \beta$ in BF cholinergic neurons further suggests that the postsynaptic effect of mGluR7 on NMDARs plays an important role in downregulating NMDA signaling.

How could $A \beta$ impair mGluR7 regulation of NMDR currents selectively in BF cholinergic neurons? Consistent with our previ- ous studies (Gu et al., 2012), the mGluR7-mediated reduction of NMDAR currents in BF neurons depends on a mechanism involving increased cofilin activity and actin depolymerization. We have found that $\mathrm{A} \beta$ treatment induces an increase in cofilin phosphorylation (deactivation) and actin polymerization selectively in cultured BF cholinergic neurons, which consequently blocks mGluR7-induced actin depolymerization in these cells (Fig. 10). Actin serves as both cytoskeleton and scaffolding proteins in neuronal synapses and thus regulates both spine morphology and synaptic plasticity (dos Remedios et al., 2003). Actin cytoskeleton is also critically involved in the trafficking of membrane receptors (Rogers and Gelfand, 2000). Previous studies by several groups, including us, have shown that the trafficking and function of NMDARs are dependent on the integrity of actin cytoskeleton (Rosenmund and Westbrook, 1993; Allison et al., 1998; Gu et al., 2005; Duffney et al., 2013). A $\beta$-induced dysfunction of the actin system is thought to be critical to A $\beta$ pathology (Song et al., 2002; Maloney et al., 2005). Persistent rod-like inclusions containing cofilin and actin, which disrupt distal neurite functions, are induced by neurodenegerative stimuli in AD conditions (Minamide et al., 2000). Our results have revealed a specific alteration of action dynamics by $\mathrm{A} \beta$ in $\mathrm{BF}$ cholinergic neurons, which leads to the impairment of mGluR7 downregulation of NMDA signaling in these cells.

To understand how $\mathrm{A} \beta$ increases cofilin phosphorylation and actin polymerization in BF cholinergic neurons, we have examined the upstream kinase of cofilin. Cofilin is phosphorylated by LIM kinase (Edwards et al., 1999), which is activated by PAK, a downstream signaling effector of the Rho/Rac family of small GTPases (Manser et al., 1994). Rho GTPases are key signaling proteins that orchestrate coordinated changes in the actin cytoskeleton essential for neurite outgrowth and synaptic connectivity (Hall, 1998; Luo, 2000). Many studies have linked PAK/ 
cofilin/actin signaling defects and the ensuing abnormal neuronal connectivity and synaptic function to mental retardation (Allen et al., 1998; Ramakers, 2002; Hayashi et al., 2004) and AD (Minamide et al., 2000; Zhao et al., 2006). In this study, we have found that $\mathrm{A} \beta$ treatment induces PAK activation selectively in $\mathrm{BF}$ cholinergic neurons, which is responsible for $\mathrm{A} \beta$-induced cofilin phosphorylation in these cells. It suggests that PAK signaling may play a unique role in the pathology of cholinergic dysfunction in $\mathrm{AD}$ patients.

How does $A \beta$ selectively activate PAK in BF cholinergic neurons? We have found that it is through a mechanism depending on $\mathrm{p} 75^{\mathrm{NTR}}$. p $75^{\mathrm{NTR}}$ can mediate the activation of Rac (Harrington et al., 2002), one of the upstream molecules of PAK. Because of the highest expression of $\mathrm{p} 75^{\mathrm{NTR}}$ in BF cholinergic neurons in adult brain (Gibbs et al., 1989) and its ability to bind to A $\beta$ (Yaar et al., 1997; Perini et al., 2002; Costantini et al., 2005), $\mathrm{p} 75^{\mathrm{NTR}}$ is likely to play a key role in the selective cholinergic degeneration in AD. Previous studies have shown that $\mathrm{p} 75^{\mathrm{NTR}}$ mediates various cellular signaling pathways in promoting both cell death and cell survival in different situations after $\mathrm{A} \beta$ treatment (Yaar et al., 1997; Perini et al., 2002; Zhang et al., 2003; Hashimoto et al., 2004; Costantini et al., 2005). Our results have revealed the specific involvement of p $75^{\mathrm{NTR}}$ in $\mathrm{A} \beta$-induced PAK activation in $\mathrm{BF}$ cholinergic neurons, suggesting that $\mathrm{p} 75^{\mathrm{NTR}}$ may determine the unique action of $\mathrm{A} \beta$ on actin dynamics and actinbased regulation of synaptic proteins in these cells.

\section{References}

Aizawa H, Wakatsuki S, Ishii A, Moriyama K, Sasaki Y, Ohashi K, SekineAizawa Y, Sehara-Fujisawa A, Mizuno K, Goshima Y, Yahara I (2001) Phosphorylation of cofilin by LIM-kinase is necessary for semaphoring 3A-induced growth cone collapse. Nat Neurosci 4:367-373. CrossRef Medline

Alger BE, Pitler TA, Wagner JJ, Martin LA, Morishita W, Kirov SA, Lenz RA (1996) Retrograde signalling in depolarization-induced suppression of inhibition in rat hippocampal CA1 cells. J Physiol 496:197-209. Medline

Allen KM, Gleeson JG, Bagrodia S, Partington MW, MacMillan JC, Cerione RA, Mulley JC, Walsh CA (1998) PAK3 mutation in nonsyndromic X-linked mental retardation. Nat Genet 20:25-30. CrossRef Medline

Allison DW, Gelfand VI, Spector I, Craig AM (1998) Role of actin in anchoring postsynaptic receptors in cultured hippocampal neurons: differential attachment of NMDA versus AMPA receptors. J Neurosci 18:24232436. Medline

Ankarcrona M, Dypbukt JM, Bonfoco E, Zhivotovsky B, Orrenius S, Lipton SA, Nicotera P (1995) Glutamate-induced neuronal death: a succession of necrosis or apoptosis depending on mitochondrial function. Neuron 15:961-973. CrossRef Medline

Ayala JE, Niswender CM, Luo Q, Banko JL, Conn PJ (2008) Group III mGluR regulation of synaptic transmission at the SC-CA1 synapse is developmentally regulated. Neuropharmacology 54:804-814. CrossRef Medline

Baldwin AN, Shooter EM (1995) Zone mapping of the binding domain of the rat low affinity nerve growth factor receptor by the introduction of novel N-glycosylation sites. J Biol Chem 270:4594-4602. CrossRef Medline

Bartus RT, Dean RL 3rd, Beer B, Lippa AS (1982) The cholinergic hypothesis of geriatric memory dysfunction. Science 217:408-414. CrossRef Medline

Basi GS1, Feinberg H, Oshidari F, Anderson J, Barbour R, Baker J, Comery TA, Diep L, Gill D, Johnson-Wood K, Goel A, Grantcharova K, Lee M, Li J, Partridge A, Griswold-Prenner I, Piot N, Walker D, Widom A, Pangalos MN, et al. (2010) Structural correlates of antibodies associated with acute reversal of amyloid beta-related behavioral deficits in a mouse model of Alzheimer disease. J Biol Chem 285:3417-3427. CrossRef Medline

Baskys A (1992) Metabotropic receptors and 'slow' excitatory actions of glutamate agonists in the hippocampus. Trends Neurosci 15:92-96. CrossRef Medline
Batchelor PE, Armstrong DM, Blaker SN, Gage FH (1989) Nerve growth factor receptor and choline acetyltransferase colocalization in neurons within the rat forebrain: response to fimbria-fornix transection. J Comp Neurol 284:187-204. CrossRef Medline

Bekkers JM, Stevens CF (1990) Presynaptic mechanism for long-term potentiation in the hippocampus. Nature 346:724-729. CrossRef Medline

Bigl V, Woolf NJ, Butcher LL (1982) Cholinergic projection from the basal forebrain to frontal, parietal, temporal, occipital, and cingulate cortices: a combined fluorescent tracer and acetylcholinesterase analysis. Brain Res Bull 8:727-749. CrossRef Medline

Bonfoco E, Krainc D, Ankarcrona M, Nicotera P, Lipton SA (1995) Apoptosis and necrosis: two distinct events induced respectively by mild and intense insults with NMDA or nitric oxide/superoxide in cortical cell cultures. Proc Natl Acad Sci U S A 92:7162-7166. CrossRef Medline

Bordji K, Becerril-Ortega J, Buisson A (2011) Synapses, NMDA receptor activity and neuronal $\mathrm{A} \beta$ production in Alzheimer's disease. Rev Neurosci 22:285-294. CrossRef Medline

Brandstätter JH, Koulen P, Kuhn R, van der Putten H, Wässle H (1996) Compartmental localization of a metabotropic glutamate receptor (mGluR7): two different active sites at a retinal synapse. J Neurosci 16 : 4749-4756. Medline

Chapman PF, White GL, Jones MW, Cooper-Blacketer D, Marshall VJ, Irizarry M, Younkin L, Good MA, Bliss TV, Hyman BT, Younkin SG, Hsiao KK (1999) Impaired synaptic plasticity and learning in aged amyloid precursor protein transgenic mice. Nat Neurosci 2:271-276. CrossRef Medline

Choi DW (1992) Excitotoxic cell death. J Neurobiol 23:1261-1276. CrossRef Medline

Conn PJ (2003) Physiological roles and therapeutic potential of metabotropic glutamate receptors. Ann N Y Acad Sci 1003:12-21. CrossRef Medline

Conn PJ, Pin JP (1997) Pharmacology and functions of metabotropic glutamate receptors. Annu Rev Pharmacol Toxicol 37:205-237. CrossRef Medline

Cosman KM, Boyle LL, Porsteinsson AP (2007) Memantine in the treatment of mild-to-moderate Alzheimer's disease. Expert Opin Pharmacother 8:203-214. CrossRef Medline

Costantini C, Rossi F, Formaggio E, Bernardoni R, Cecconi D, Della-Bianca V (2005) Characterization of the signaling pathway downstream p75 neurotrophin receptor involved in $\beta$-amyloid peptide-dependent cell death. J Mol Neurosci 25:141-156. CrossRef Medline

Coyle JT, Price DL, DeLong MR (1983) Alzheimer's disease: a disorder of cortical cholinergic innervation. Science 219:1184-1190. CrossRef Medline

Cummings JL (2004) Treatment of Alzheimer's disease: current and future therapeutic approaches. Rev Neurol Dis 1:60-69. Medline

Dahlgren KN, Manelli AM, Stine WB Jr, Baker LK, Krafft GA, LaDu M) (2002) Oligomeric and fibrillar species of amyloid-beta peptides differentially affect neuronal viability. J Biol Chem 277:32046-32053. CrossRef Medline

Danysz W, Parsons CG (2012) Alzheimer's disease, $\beta$-amyloid, glutamate, NMDA receptors and memantine: searching for the connections. $\mathrm{Br}$ J Pharmacol 167:324-352. CrossRef Medline

Deng Y, Xiong Z, Chen P, Wei J, Chen S, Yan Z (2014) $\beta$-amyloid impairs the regulation of $N$-methyl-D-aspartate receptors by glycogen synthase kinase 3. Neurobiol Aging 35:449-459. CrossRef Medline

Doble A (1999) The role of excitotoxicity in neurodegenerative disease: implications for therapy. Pharmacol Ther 81:163-221. CrossRef Medline

Doraiswamy PM (2003) Alzheimer's disease and the glutamate NMDA receptor. Psychopharmacol Bull 37:41-49. Medline

dos Remedios CG, Chhabra D, Kekic M, Dedova IV, Tsubakihara M, Berry DA, Nosworthy NJ (2003) Actin binding proteins: regulation of cytoskeletal microfilaments. Physiol Rev 83:433-473. CrossRef Medline

Duffney LJ, Wei J, Cheng J, Liu W, Smith KR, Kittler JT, Yan Z (2013) Shank3 deficiency induces NMDA receptor hypofunction via an actindependent mechanism. J Neurosci 33:15767-15778. CrossRef Medline

Dunnett SB, Whishaw IQ, Bunch ST, Fine A (1986) Acetylcholine-rich neuronal grafts in the forebrain of rats: effects of environmental enrichment, neonatal noradrenaline depletion, host transplantation site and regional source of embryonic donor cells on graft size and acetylcholinesterasepositive fibre outgrowth. Brain Res 378:357-373. CrossRef Medline

Duvoisin RM, Zhang C, Ramonell K (1995) A novel metabotropic gluta- 
mate receptor expressed in the retina and olfactory bulb. J Neurosci 15: 3075-3083. Medline

Edwards DC, Sanders LC, Bokoch GM, Gill GN (1999) Activation of LIMkinase by Pak1 couples Rac/Cdc42 GTPase signalling to actin cytoskeletal dynamics. Nat Cell Biol 1:253-259. CrossRef Medline

Faber DS, Korn H (1991) Applicability of the coefficient of variation method for analyzing synaptic plasticity. Biophys J 60:1288-1294. CrossRef Medline

Florez-McClure ML, Linseman DA, Chu CT, Barker PA, Bouchard RJ, Le SS, Laessig TA, Heidenreich KA (2004) The p75 neurotrophin receptor can induce autophagy and death of cerebellar Purkinje neurons. J Neurosci 24:4498-4509. CrossRef Medline

Gatti A, Huang Z, Tuazon PT, Traugh JA (1999) Multisite autophosphorylation of p21-activated protein kinase gamma-PAK as a function of activation. J Biol Chem 274:8022-8028. CrossRef Medline

Gereau RW 4th, Conn PJ (1995) Multiple presynaptic metabotropic glutamate receptors modulate excitatory and inhibitory synaptic transmission in hippocampal area CA1. J Neurosci 15:6879-6889. Medline

Gibbs RB, McCabe JT, Buck CR, Chao MV, Pfaff DW (1989) Expression of NGF receptor in the rat forebrain detected with in situ hybridization and immunohistochemistry. Brain Res Mol Brain Res 6:275-287. CrossRef Medline

Griffith WH, Taylor L, Davis MJ (1994) Whole-cell and single-channel calcium currents in guinea pig basal forebrain neurons. J Neurophysiol 71: 2359-2376. Medline

Gritti I, Mainville L, Jones BE (1993) Codistribution of GABA with acetylcholine-synthesizing neurons in the basal forebrain of the rat. J Comp Neurol 329:438-457. CrossRef Medline

Gu Z, Jiang Q, Fu AK, Ip NY, Yan Z (2005) Regulation of NMDA receptor currents by neuregulin signaling in prefrontal cortical neurons. J Neurosci 25:4974-4984. CrossRef Medline

Gu Z, Jiang Q, Yan Z (2007) RGS4 modulates serotonin signaling in prefrontal cortex and links to serotonin dysfunction in a rat model of schizophrenia. Mol Pharmacol 71:1030-1039. CrossRef Medline

Gu Z, Liu W, Yan Z (2009) $\beta$-Amyloid impairs AMPA receptor trafficking and function by reducing CaMKII synaptic distribution. J Biol Chem 284:10639-10649. CrossRef Medline

Gu Z, Liu W, Wei J, Yan Z (2012) Regulation of NMDA receptors by metabotropic glutamate receptor 7. J Biol Chem 287:10265-10275. CrossRef Medline

Gubellini P, Pisani A, Centonze D, Bernardi G, Calabresi P (2004) Metabotropic glutamate receptors and striatal synaptic plasticity: implications for neurological diseases. Prog Neurobiol 74:271-300. CrossRef Medline

Haass C, Selkoe DJ (2007) Soluble protein oligomers in neurodegeneration: lessons from the Alzheimer's amyloid beta-peptide. Nat Rev Mol Cell Biol 8:101-112. CrossRef Medline

Hall A (1998) Rho GTPases and the actin cytoskeleton. Science 279:509514. CrossRef Medline

Hardy JA, Higgins GA (1992) Alzheimer's disease: the amyloid cascade hypothesis. Science 256:184-185. CrossRef Medline

Harrington AW, Kim JY, Yoon SO (2002) Activation of Rac GTPase by p75 is necessary for c-jun $\mathrm{N}$-terminal kinase-mediated apoptosis. J Neurosci 22:156-166. Medline

Hartman RE, Izumi Y, Bales KR, Paul SM, Wozniak DF, Holtzman DM (2005) Treatment with an amyloid-beta antibody ameliorates plaque load, learning deficits, and hippocampal long-term potentiation in a mouse model of Alzheimer's disease. J Neurosci 25:6213-6220. CrossRef Medline

Hashimoto Y, Kaneko Y, Tsukamoto E, Frankowski H, Kouyama K, Kita Y, Niikura T, Aiso S, Bredesen DE, Matsuoka M, Nishimoto I (2004) Molecular characterization of neurohybrid cell death induced by Alzheimer's amyloid- $\beta$ peptides via p75NTR/PLAIDD. J Neurochem 90:549-558. CrossRef Medline

Hayashi ML, Choi SY, Rao BS, Jung HY, Lee HK, Zhang D, Chattarji S, Kirkwood A, Tonegawa S (2004) Altered cortical synaptic morphology and impaired memory consolidation in forebrain-specific dominantnegative PAK transgenic mice. Neuron 42:773-787. CrossRef Medline

Hsiao K, Chapman P, Nilsen S, Eckman C, Harigaya Y, Younkin S, Yang F, Cole G (1996) Correlative memory deficits, abeta elevation, and amyloid plaques in transgenic mice. Science 274:99-102. CrossRef Medline

Jassar BS, Harris KH, Ostashewski PM, Jhamandas JH (1999) Ionic mecha- nisms of action of neurotensin in acutely dissociated neurons from the diagonal band of Broca of the rat. J Neurophysiol 81:234-246. Medline

Kinzie JM, Shinohara MM, van den Pol AN, Westbrook GL, Segerson TP (1997) Immunolocalization of metabotropic glutamate receptor 7 in the rat olfactory bulb. J Comp Neurol 385:372-384. CrossRef Medline

Kosinski CM, Risso Bradley S, Conn PJ, Levey AI, Landwehrmeyer GB, Penney JB Jr, Young AB, Standaert DG (1999) Localization of metabotropic glutamate receptor $7 \mathrm{mRNA}$ and mGluR7a protein in the rat basal ganglia. J Comp Neurol 415:266-284. CrossRef Medline

Luo L (2000) Rho GTPases in neuronal morphogenesis. Nat Rev Neurosci 1:173-180. CrossRef Medline

Maloney MT, Minamide LS, Kinley AW, Boyle JA, Bamburg JR (2005) Betasecretase-cleaved amyloid precursor protein accumulates at actin inclusions induced in neurons by stress or amyloid beta: a feedforward mechanism for Alzheimer's disease. J Neurosci 25:11313-11321. CrossRef Medline

Manabe T, Wyllie DJ, Perkel DJ, Nicoll RA (1993) Modulation of synaptic transmission and long-term potentiation: effects on paired pulse facilitation and EPSC variance in the CA1 region of the hippocampus. J Neurophysiol 70:1451-1459. Medline

Manser E, Leung T, Salihuddin H, Zhao ZS, Lim L (1994) A brain serine/ threonine protein kinase activated by $\mathrm{Cdc} 42$ and Rac1. Nature 367:4046. CrossRef Medline

Martín R, Torres M, Sánchez-Prieto J (2007) mGluR7 inhibits glutamate release through a PKC-independent decrease in the activity of P/Q-type $\mathrm{Ca}^{2+}$ channels and by diminishing cAMP in hippocampal nerve terminals. Eur J Neurosci 26:312-322. CrossRef Medline

Mattson MP, Barger SW, Cheng B, Lieberburg I, Smith-Swintosky VL, Rydel RE (1993) beta-Amyloid precursor protein metabolites and loss of neuronal $\mathrm{Ca}^{2+}$ homeostasis in Alzheimer's disease. Trends Neurosci 16:409414. CrossRef Medline

McGeer PL, McGeer EG, Suzuki J, Dolman CE, Nagai T (1984) Aging, Alzheimer's disease and the cholinergic system of the basal forebrain. Neurology 34:741-745. CrossRef Medline

Mesulam MM, Mufson EJ (1984) Neural inputs into the nucleus basalis' of the substantia innominata (Ch4) in the rhesus monkey. Brain 107:253274. CrossRef Medline

Minamide LS, Striegl AM, Boyle JA, Meberg PJ, Bamburg JR (2000) Neurodegenerative stimuli induce persistent $\mathrm{ADF} /$ cofilin-actin rods that disrupt distal neurite function. Nat Cell Biol 2:628-636. CrossRef Medline

Morgan TE, Lockerbie RO, Minamide LS, Browning MD, Bamburg JR (1993) Isolation and characterization of a regulated form of actin depolymerizing factor. J Cell Biol 122:623-633. CrossRef Medline

Muir JL (1997) Acetylcholine, aging, and Alzheimer's disease. Pharmacol Biochem Behav 56:687-696. CrossRef Medline

Nakajima Y, Nakajima S, Obata K, Carlson CG, Yamaguchi K (1985) Dissociated cell culture of cholinergic neurons from nucleus basalis of Meynert and other basal forebrain nuclei. Proc Nati Acad Sci U S A 82: 6325-6329. CrossRef Medline

Nakajima Y, Iwakabe H, Akazawa C, Nawa H, Shigemoto R, Mizuno N, Nakanishi S (1993) Molecular characterization of a novel retinal metabotropic glutamate receptor mGluR6 with a high agonist selectivity for L-2-amino-4-phosphonobutyrate. J Biol Chem 268:11868-11873. Medline

Ohishi H, Akazawa C, Shigemoto R, Nakanishi S, Mizuno N (1995) Distributions of the mRNAs for L-2-amino-4-phosphonobutyrate-sensitive metabotropic glutamate receptors, mGluR4 and mGluR7, in the rat brain. J Comp Neurol 360:555-570. CrossRef Medline

Pelkey KA, Topolnik L, Lacaille JC, McBain CJ (2006) Compartmentalized $\mathrm{Ca}(2+)$ channel regulation at divergent mossy-fiber release sites underlies target cell-dependent plasticity. Neuron 52:497-510. CrossRef Medline

Perini G, Della-Bianca V, Politi V, Della Valle G, Dal-Pra I, Rossi F, Armato U (2002) Role of p75 neurotrophin receptor in the neurotoxicity by betaamyloid peptides and synergistic effect of inflammatory cytokines. J Exp Med 195:907-918. CrossRef Medline

Perry EK, Tomlinson BE, Blessed G, Bergmann K, Gibson PH, Perry RH (1978) Correlation of cholinergic abnormalities with senile plaques and mental test scores in senile dementia. Br Med J 2:1457-1459. CrossRef Medline

Ramakers GJ (2002) Rho proteins, mental retardation and the cellular basis of cognition. Trends Neurosci 25:191-199. CrossRef Medline 
Rogers SL, Gelfand VI (2000) Membrane trafficking, organelle transport, and the cytoskeleton. Curr Opin Cell Biol 12:57-62. CrossRef Medline

Rosenmund C, Westbrook GL (1993) Calcium-induced actin depolymerization reduces NMDA channel activity. Neuron 10:805-814. CrossRef Medline

Rye DB, Wainer BH, Mesulam MM, Mufson EJ, Saper CB (1984) Cortical projections arising from the basal forebrain: a study of cholinergic and noncholinergic components using combined retrograde tracing and immunohistochemical localization of choline acetyltransferase, Neuroscience 13:627-643. CrossRef

Schoepp DD, Conn PJ (1993) Metabotropic glutamate receptors in brain function and pathology. Trends Pharmacol Sci 14:13-20. CrossRef Medline

Schoepp DD, Jane DE, Monn JA (1999) Pharmacological agents acting at subtypes of metabotropic glutamate receptors. Neuropharmacology 38 : 1431-1476. CrossRef Medline

Sivanesan S, Tan A, Rajadas J (2013) Pathogenesis of Abeta oligomers in synaptic failure. Curr Alzheimer Res 10:316-323. CrossRef Medline

Song C, Perides G, Wang D, Liu YF (2002) beta-Amyloid peptide induces formation of actin stress fibers through p38 mitogen-activated protein kinase. J Neurochem 83:828-836. CrossRef Medline

Swaab DF, Hofman MA, Lucassen PJ, Salehi A, Uylings HB (1994) Neuronal atrophy, not cell death, is the main hallmark of Alzheimer's disease. Neurobiol Aging 15:369-371; discussion 379-380. CrossRef Medline

Vogels OJ, Broere CA, ter Laak HJ, ten Donkelaar HJ, Nieuwenhuys R, Schulte BP (1990) Cell loss and shrinkage in the nucleus basalis Meynert complex in Alzheimer's disease. Neurobiol Aging 11:3-13. CrossRef Medline

Wenk GL, Willard LB (1998) The neural mechanisms underlying cholin- ergic cell death within the basal forebrain. Int J Dev Neurosci 16:729-735. CrossRef Medline

Whitehouse PJ, Price DL, Struble RG, Clark AW, Coyle JT, DeLon MR (1982) Alzheimer's disease and senile dementia: loss of neurons in the basal forebrain. Science 215:1237-1239. CrossRef Medline

Whittemore ER, Loo DT, Watt JA, Cotman CW (1995) A detailed analysis of hydrogen peroxide-induced cell death in primary neuronal culture. Neuroscience 67:921-932. CrossRef Medline

Winkler J, Suhr ST, Gage FH, Thal LJ, Fisher LJ (1995) Essential role of neocortical acetylcholine in spatial memory. Nature 375:484-487. CrossRef Medline

Yaar M, Zhai S, Pilch PF, Doyle SM, Eisenhauer PB, Fine RE, Gilchrest BA (1997) Binding of $\beta$-amyloid to the p75 neurotrophin receptor induces apoptosis: a possible mechanism for Alzheimer's disease. J Clin Invest 100:2333-2340. CrossRef Medline

Zaborszky L, Gaykema RP, Swanson DJ, Cullinan WE (1997) Cortical input to the basal forebrain. Neuroscience 79:1051-1078. CrossRef Medline

Zenke FT, King CC, Bohl BP, Bokoch GM (1999) Identification of a central phosphorylation site in p21-activated kinase regulating autoinhibition and kinase activity. J Biol Chem 274:32565-32573. CrossRef Medline

Zhang Y, Hong Y, Bounhar Y, Blacker M, Roucou X, Tounekti O, Vereker E, Bowers WJ, Federoff HJ, Goodyer CG, LeBlanc A (2003) p75 neurotrophin receptor protects primary cultures of human neurons against extracellular amyloid beta peptide cytotoxicity. J Neurosci 23:7385-7394. Medline

Zhao L, Ma QL, Calon F, Harris-White ME, Yang F, Lim GP, Morihara T, Ubeda OJ, Ambegaokar S, Hansen JE, Weisbart RH, Teter B, Frautschy SA, Cole GM (2006) Role of p21-activated kinase pathway defects in the cognitive deficits of Alzheimer disease. Nat Neurosci 9:234-242. CrossRef Medline 